Article

\title{
An Environmental Assessment of Heat Pumps in Poland
}

\author{
Sara Sewastianik ${ }^{1}$ (D) and Andrzej Gajewski ${ }^{2, *(D)}$ \\ 1 Students' Scientific Society “Heat Engineer”, Faculty of Civil Engineering and Environmental Sciences, \\ Bialystok University of Technology, Wiejska Street 45 A, 15-351 Białystok, Poland; \\ s.sewastianik@doktoranci.pb.edu.pl \\ 2 Department of HVAC Engineering, Faculty of Civil Engineering and Environmental Sciences, \\ Bialystok University of Technology, Wiejska Street 45 A, 15-351 Białystok, Poland \\ * Correspondence: a.gajewski@pb.edu.pl; Tel.: +48-797-995-923
}

Citation: Sewastianik, S.; Gajewski, A. An Environmental Assessment of Heat Pumps in Poland. Energies 2021, 14, 8104. https://doi.org/10.3390/ en14238104

Academic Editor: Antonio Rodero Serrano

Received: 3 September 2021

Accepted: 24 November 2021

Published: 3 December 2021

Publisher's Note: MDPI stays neutral with regard to jurisdictional claims in published maps and institutional affiliations.

Copyright: (c) 2021 by the authors. Licensee MDPI, Basel, Switzerland. This article is an open access article distributed under the terms and conditions of the Creative Commons Attribution (CC BY) license (https:/ / creativecommons.org/licenses/by/ $4.0 /)$.

\begin{abstract}
Greenhouse gas emissions are regarded as the cause of the rise in mean Earth temperature, the further increase of which may cause dramatic irreversible global changes. Their levels in Poland are some of the highest in the world. In this study, to evaluate the "Energy policy of Poland until 2040", greenhouse gas and particulate matter emissions were compared in all Polish climatic zones using a typical meteorological year. A comparison was made between air-to-water, brine-to-water, and water-to-water devices. The electrical energy consumption and coefficient of performance were determined hourly in the heating season. The determining algorithm took a buffer tank or separating heat exchanger into consideration, when they were required, and electricity transmission efficiency. Subsequently the emissions were estimated for the present Polish energy mix and a mix proposed in the "Energy policy of Poland until 2040". After implementing this policy all heat pumps will be energetically viable devices. However, only in one location will water-to-water heat pumps cause less emissions than a condensing gas boiler. In other cases, condensing gas boilers will be significantly less emissive devices. Therefore, this policy is insufficient for reducing emissions. Hence, it is necessary to replace almost all coal-fired power plants with natural gas-fired gas turbines in a transitional period.
\end{abstract}

Keywords: seasonal coefficient of performance; Polish energy mix; Energy policy of Poland until 2040; greenhouse gas emissions; particulate matter emissions

\section{Introduction}

On 8 August, 2019, the Intergovernmental Panel on Climate Change (IPCC) published a report on climate and land changes. Its content clearly indicates the consequences that would ensue if the average annual temperature rose by $1.5{ }^{\circ} \mathrm{C}$; humanity will face with problems including access to drinking water, soil desertification, violent weather phenomena, including prolonged droughts and floods, and food safety. In addition, this document indicated that changes have already been taking place, e.g., shifts in climatic zones, yield reductions in some regions of the world, and variations in the abundance or seasonal activity of some plant or animal species. The excessive emission of greenhouse gases is invariably indicated as one of the reasons for the progressive degradation of our planet. This document caused a great stir not only because it clearly indicates the consequences and risks of a further increase in the average temperature, but it clearly states a need to fulfill new regulations for reducing greenhouse gas emissions [1].

Numerous states and the international organizations, including the European Union, have introduced new solutions aimed at preventing further destructive human activity. In addition to the previously used mechanisms which include, among others, the Emissions Trading System (EU ETS) or financial support for technologies based on renewable energy sources (RES), the better solutions are being increasingly looked for so as to achieve an ambitious goal that is the neutral impact of human activity on climatic changes. According to the assumptions of the climate and energy framework, by 2030 , at least a $40 \%$ reduction 
in greenhouse gas emissions is assumed in comparison to the value from 1990, as well as at least a $32 \%$ share of renewable energy and at least a 32.5\% improvement in energy efficiency [2]. Moreover, according to the assumptions of the European Green Deal, Europe should become the first continent with a neutral impact on the climate by 2050, with the implementation of a closed loop economy. The plan also aims to restore biodiversity and reduce the amount of the contaminants emitted to the environment, which is aimed to be achieved through international cooperation focused on supporting green technologies, decarbonizing the energy sector or improving the energy efficiency of new and existing facilities [3]. These plans are also written as a part of the promotional and preparatory activities until 2050 [4].

The carbon dioxide generation factor for the production of electricity in Poland $\left(0.8460 \mathrm{kgCO}_{2} / \mathrm{kWh}\right)$ is one of the highest values in the world; higher values are found in South Africa (0.9606 $\left.\mathrm{kgCO}_{2} / \mathrm{kWh}\right)$ and Estonia $\left(0.8750 \mathrm{kgCO}_{2} / \mathrm{kWh}\right)$. Other heavily industrialized countries maintain lower emission levels, e.g., China (PR) $\left(0.6236 \mathrm{kgCO}_{2} / \mathrm{kWh}\right)$, Hong Kong (China) (0.8000 $\left.\mathrm{kgCO}_{2} / \mathrm{kWh}\right)$, Australia $\left(0.8000 \mathrm{kgCO}_{2} / \mathrm{kWh}\right)$, Canada $\left(0.1300 \mathrm{kgCO}_{2} / \mathrm{kWh}\right)$, the United States $\left(0.47590 \mathrm{kgCO}_{2} / \mathrm{kWh}\right)$, the United Kingdom $\left(0.2773 \mathrm{kgCO}_{2} / \mathrm{kWh}\right)$, France $\left(0.0470 \mathrm{kgCO}_{2} / \mathrm{kWh}\right)$, Germany $\left(0.4690 \mathrm{kgCO}_{2} / \mathrm{kWh}\right)$ and the Russian Federation (0.3302 $\left.\mathrm{kgCO}_{2} / \mathrm{kWh}\right)$ [5].

For this reason, Poland has conducted multidirectional activities aimed at reducing greenhouse gas emissions, thus contributing to the inhibition of the greenhouse effect. One such measure is planned changes in the energy sector; these changes are aimed at increasing the share of nonemission electricity production and improving energy efficiency. This goal is to be achieved through the development of RES, e.g., by increasing the share of photovoltaic micro-installations and constructing nuclear power plants [6].

In addition to the central solutions focusing on large investments, parallel activities are being carried out to promote and support the improvement of the energy efficiency of facilities, paying particular attention to individual households. One of the solutions in the field of space heating is to promote installations in which heat is generated by heat pumps. These devices absorb ambient energy from the air, water or ground and deliver higher-temperature heat to a building using a vapor compression cycle. Depending on the type of device, the air, water or ground can be a heat reservoir [7-9]. The ratio between the amount of heat produced by the device and the amount of work supplied to the driving device is known as the coefficient of energy performance (COP) [10], whose value depends, inter alia, on the heat source temperature and its variability. Since ground temperatures vary slightly from ambient air temperatures, ground heat exchangers are coupled to heat pumps to achieve higher COP values [11]. Other important factors that affect COP values are the type and temperature of medium used in central heating systems, the number and type of compressors, or the additional functions performed by the device (e.g., domestic hot water heating or cooling) [9].

The impact of hydrogeological, geological, and climatic conditions on designing and operating a brine-to-water heat pump (GSHP) was investigated in Baden-Württemberg state [12]. No effect of subsurface characteristics on the applied technical solutions or economic factors was found. Thus, these characteristics may not have been investigated thoroughly before ordering GSHPs.

The amount of carbon dioxide emissions avoided because of GSHP operations are $80 \mathrm{gCO}_{2} / \mathrm{kWh}$ or $164 \mathrm{gCO}_{2} / \mathrm{kWh}$. These savings depend on the assumed energy mix; the lower value is for the average German mix, while the bigger savings are for BadenWürttemberg state, where 55\% of energy is produced in a nuclear power station [13].

The energy consumption of GSHPs coupled with Borehole Thermal Energy Storage (BTES) in Aalto University, located in Otaniemi (Espoo) in Finland, was recorded from October 2019 to September 2020 [14]. The yearly averaged coefficient of performance (COP) was 3.7; after adding energy consumption for driving the circulating pumps of BTES, the COP dropped to 3.5 . 
Exergy analysis for a detached house in Ljubljana [15] indicated the highest exergetic efficiency of 0.47 was achieved by a GSHP, followed by are a water-to-water heat pump (WSHP), air-to-water heat pump (ASHP) and gas boiler (GB), with the efficiencies of 0.45 , 0.41 and 0.09 , respectively.

A creative approach to exergy analysis was developed in [16], where two methods of exergy analysis were compared: local (direct exergy analysis) and global (system exergy analysis). While the former indicated that a higher RES percentage decreases the exergy efficiency, which leads to erroneous conclusions, the latter gave the opposite and logical outcome that this higher percentage increases the exergy efficiency.

A life cycle assessment (LCA) was made for a residential building in New Jersey [17]. The environmental impact of a $10.55 \mathrm{~kW}$ GSHP was calculated over 25 years. This study examined impact of drilling, producing and installing two borehole loops, operating and maintaining a heat pump system and treating wastes. Similarly, as in the above studies, over $50 \%$ of the emissions were caused by space heating. The heat pump had a lower impact on the environment than a natural gas boiler in 8 out of 18 categories, e.g., the smaller factors are GWP, ODP and PM formation. Another LCA [18] was undertaken for a semi-detached house in the UK constructed in 1930s; the analysis was performed for two variants of heat generator: a $24 \mathrm{~kW}$ condensing gas boiler (CGB) and a hybrid system (HHP) consisting of a $10 \mathrm{~kW}$ ASHP and $10 \mathrm{~kW}$ condensing gas boiler. The HHP caused lower GWP and PM formation than the CGB, whilst the ODP was slightly higher. However, none of these studies included the efficiency of the electricity transmission, which favors heat pumps over boilers.

Similar investigations of a greenhouse located in Chungcheongnam-do Province in South Korea [19] revealed the energy consumption share was $41-96 \%$ of the total emissions caused by its construction and exploitation. The biggest global warming impact (GWP) was exerted by a kerosene-powered boiler, followed by an electric-powered heat pump (above two times lower GWP) and heat-powered absorption heat pump (4 times lower GWP).

Another LCA of a detached house was carried out in terms of the social costs of $\mathrm{CO}_{2}$ emissions [20]. This building was located in the third climatic zone in Poland. Four methods of energy provision were investigated: burning coal plus supplying electricity from the grid, burning coal plus generating heat in solar collectors plus supplying electricity from the grid, burning coal plus generating electricity in photovoltaic panels and generating heat in an ASHP plus supplying electricity from the grid. The lowest $\mathrm{CO}_{2}$ emissions were measured in the last variant with an ASHP; they were six times lower than in the first variant. The energy consumption represented $58-90 \%$ of the total $\mathrm{CO}_{2}$ emissions from constructing and using the building.

A GSHP that used a one-stage system with an internal heat exchanger and sub-cooler filled with $\mathrm{CO}_{2}$ as a refrigerator was the subject of a theoretical analysis in Mediterranean climatic conditions [21]. Because the flow water temperature in a heating system is higher than the critical temperature of $\mathrm{CO}_{2}$, the heat pump works in transcritical mode. The $\mathrm{COP}$ value increased from 3.371 to 4.620 as the ground temperature rose from $10^{\circ} \mathrm{C}$ to $22^{\circ} \mathrm{C}$. Four parameters had the biggest impact on the COP value: the refrigerant temperature after heating a hydronic system, the number of boreholes, the ground temperature and the pressure in the evaporator.

Another method for lessening the total equivalent warming impact (TEWI) of the heat pumps are alternative refrigerants with low GWP values; such analyses were performed in Brazil, Canada, Poland and Sweden [22]. The highest TEWI was found to be in Poland because of the large share of coal and lignite in electricity production. Possible very good replacements for R134a and R245fa are R1234ze(Z) and R1336mzz(Z), respectively; these replacements provide the biggest TEWI reduction and the highest COP value in the discharge temperature range of $50-70{ }^{\circ} \mathrm{C}$.

The inlet and outlet temperatures of brine, external temperatures, the operation time of GSHP, and energy consumed were measured between October 2011 and September 2013 
in the third climatic zone in Poland [23]. This energy consumption in location was applied in computations of the primary energy demand in four variants. Variant A assumed electricity generation in a coal-fired power plant with an efficiency of $38 \%$; electricity in variant $\mathrm{B}$ was produced by a gas-steam plant with the efficiency of $48 \%$; the transformation and transmission efficiency in both variants was $90 \%$. Variant $C$ assumed heat production in a coal-fired boiler station with efficiency of $88 \%$ and heat supply with efficiency $95 \%$. Finally, in variant D, heat was generated in a local gas boiler with efficiency $92 \%$. The primary energy consumed was lowest in variant $B$, followed by $A$ and $D$, and its highest consumption was in variant $C$.

A multivalent installation was monitored in a residential and retail building with the designed heat load of $56 \mathrm{kWh}$. This building is located in Kraków (Poland) in the third climatic zone in Poland. The installed heat pump, Vaillant geoTHERM plus VWS 104/2, had a heating capacity of $10.4 \mathrm{~kW}$ with $\mathrm{COP}=4.4$ for $\mathrm{B} 0 / \mathrm{W} 35^{\circ} \mathrm{C}$. The experimentally obtained seasonal performance factor of GSHP was between 3.49 and 3.83 in the years 2012-2017 [24].

Drops in temperature in the ground because of GSHP operation was investigated in Świdnica (third climatic zone in Poland) for a heat pump with nominal thermal power of $17 \mathrm{~kW}$ and $\mathrm{COP}$ of 4.4 for $\mathrm{B} 0 / \mathrm{W} 35^{\circ} \mathrm{C}$; the ground heat exchanger consisted of five U-pipes $(\mathrm{PE} 40 \times 4 \mathrm{~mm}) 78 \mathrm{~m}$ deep. The average temperature drop was between 0.3 and $1.1 \mathrm{~K}$ [25]. Further research suggested the ground temperature was reduced by $0.76 \mathrm{~K}$ per year [26]. Similar investigations were carried out in Białystok (fourth climatic zone in Poland) for a GSHP with nominal thermal power at $7.8 \mathrm{~kW}$ and COP of 4.7 for $\mathrm{B} 5 / \mathrm{W} 35^{\circ} \mathrm{C}$ and a similar heat exchanger with a depth of $100 \mathrm{~m}$. The average temperature drop was $1.89^{\circ} \mathrm{C}$ [27].

The impact of heat pumps on the environment is illustrated by the value of a seasonal performance factor which takes into account the amount of work transferred from an electrical grid [8,9]. Another environmental parameter is carbon dioxide emissions [7,8,28], which was investigated in European countries using different methods, e.g., life cycle assessment [7,8] or TEWI [28]; despite the different scientific approaches used, these studies yielded similar conclusions that heat pumps in Poland are not ecologically viable in terms of the Polish energy market in the 2010s [29]. Undoubtedly, condensing natural gas boilers emit less $\mathrm{CO}_{2}$ directly in a certain location than heat pumps emit indirectly in power stations $[7,28]$.

Although the work needed to drive heat pumps decreases when a performance factor increases, it is never null due to the second law of thermodynamics. Thus, electrical energy should be produced in a non-emissive way. One such method is electricity production via photovoltaic micro-installations which cover the needs of a building instead of electricity production by burning high-emission fossil fuels. However, the solar irradiance is highest outside of the heating season, while at the peak demand for heat, solar irradiance is at its lowest.

Currently, the Polish Organization for the Development of Heat Pump Technology (PORT PC) estimates that by 2030, the share of heat pumps in single-family buildings will amount to $10 \%$ in the probable scenario and $22.8 \%$ in the optimistic scenario [30]. These forecasts, combined with the planned changes in the power industry, will significantly reduce the emission of greenhouse gases, such as carbon dioxide, sulfur oxides and nitrogen oxides, to the atmosphere as a result of heating buildings. This activity also affects the longterm improvement of air quality in large cities during winter periods, which contributes to improvements in the health of the people living in them. In addition, such solutions are economically viable, as they are cheaper to operate than a condensing gas boiler, and at the investment stage, it is possible to obtain financial support through various types of local or central programs [9].

The aim of this research is to determine the emissions levels of selected greenhouse gases (carbon dioxide, sulfur dioxide, nitrogen oxides and particulate matter (PM)) during winter operation, as well as the computation of the seasonal coefficient of performance $\left(\mathrm{SCOP}_{\text {net }}\right)$. This analysis is performed with much more reliable climatic conditions and 
generation factors regarding pollutants emission than those that have been previously used [31]; moreover, there is more RES in the Polish energy mix; hence, differences are expected in comparison to previous estimations.

Another aim of this research is to evaluate the changes recently made to the Polish energy mix and planned in the "Energy policy of Poland until 2040" [32].

\section{Materials and Methods}

The analysis covered the heat supply to a building whose total designed heat load was $46 \mathrm{~kW}$, and a heating system was extended with two buffer tanks, each with a $500 \mathrm{~L}$ capacity, to maintain the proper performance of a heat pump. Heat from the heat pump transferred in the condenser to the hydronic heating system at a designed supply water temperature of $45^{\circ} \mathrm{C}$; the designed return water temperature was $35^{\circ} \mathrm{C}$.

The operation period was assumed to be a heating season, which was determined by the climatic zone for which the analysis was performed. One location was used from each of these 5 zones in Poland: Szczecin, Poznań, Łódź, Białystok and Zakopane; the hourly climatic temperatures were taken from a typical meteorological year (TMY) published on the EnergyPlus portal [33]; they were the input data in computing the average annual air temperature, $t_{a}$; the last column shows the results in each location. The four most commonly applied heat pumps were analyzed: ASHP, GSHP and WSHP; the last one was equipped with a separating heat exchanger (WSHP + SHE) that is an additional unit to protecting the system against the negative effects of water groundwater; Table 1 enumerates the selected types of heat pumps and supplemental devices; Tables 2-4 present technical data of the selected heat pumps, whilst Table 5 shows the list of the climatic zones in Poland with the analyzed locations and the values of the designed external temperature.

Table 1. Types of compared heat pumps and supplementary devices manufactured by the Dimplex company.

\begin{tabular}{cc}
\hline Type of Element & Name of the Series \\
\hline Air-to-water heat pump (ASHP) & LA 60S-TU \\
Brine-to-water heat pump (GSHP) & SI 50TU \\
Water-to-water heat pump (WSHP) & WI 45TU \\
Buffer tank & PSW 500 \\
Separating heat exchanger (SHE) & WTE 75 \\
\hline
\end{tabular}

Table 2. Technical data heat pump LA 60S-TU, manufactured by the Dimplex company.

\begin{tabular}{|c|c|c|}
\hline Parameter & Unit & Value \\
\hline $\begin{array}{l}\text { Heating power ( } 1 \text { compressor operation, } \\
\text { A-7/W35) }\end{array}$ & $\mathrm{kW}$ & 22.2 \\
\hline COP (1 compressor operation, A-7/W35) & - & 3.2 \\
\hline $\begin{array}{l}\text { Heating power ( } 1 \text { compressor operation, } \\
\text { A2/W35) }\end{array}$ & $\mathrm{kW}$ & 26.6 \\
\hline COP (1 compressor operation, A2/W35) & - & 3.6 \\
\hline $\begin{array}{l}\text { Heating power (1 compressor operation, } \\
\text { A7/W35) }\end{array}$ & $\mathrm{kW}$ & 35.3 \\
\hline COP (1 compressor operation, A7/W35) & - & 4.5 \\
\hline $\begin{array}{l}\text { Heating power (2 compressor operation, } \\
\qquad \mathrm{A}-7 / \mathrm{W} 35)\end{array}$ & $\mathrm{kW}$ & 36 \\
\hline COP (2 compressor operation, A-7/W35) & - & 3 \\
\hline $\begin{array}{l}\text { Heating power ( } 2 \text { compressor operation, } \\
\text { A2/W35) }\end{array}$ & $\mathrm{kW}$ & 43.4 \\
\hline COP (2 compressor operation, A2/W35) & - & 3.4 \\
\hline Maximum flow temperature & ${ }^{\circ} \mathrm{C}$ & 62 \\
\hline Heat source application limit (heating mode) & ${ }^{\circ} \mathrm{C}$ & $-22 / 40$ \\
\hline Type of refrigerant & - & R407C \\
\hline
\end{tabular}


Table 3. Technical data heat pump SI 50TU, manufactured by the Dimplex company.

\begin{tabular}{ccc}
\hline Parameter & Unit & Value \\
\hline Heating power (1 compressor operation, B0/W35) & $\mathrm{kW}$ & 27.4 \\
COP (1 compressor operation, B0/W35) & - & 5.4 \\
Heating power (1 compressor operation, B10/W35) & $\mathrm{kW}$ & 37 \\
COP (1 compressor operation, B10/W35) & - & 7.1 \\
Heating power (2 compressor operation, B0/W35) & $\mathrm{kW}$ & 52 \\
COP (2 compressor operation, B0/W35) & - & 5 \\
Heating power (2 compressor operation, B10/W35) & $\mathrm{kW}$ & 68.1 \\
COP (2 compressor operation, B10/W35) & - & 6.8 \\
Maximum flow temperature & ${ }^{\circ} \mathrm{C}$ & 62 \\
Heat source application limit (heating mode) & ${ }^{\circ} \mathrm{C}$ & $-5 / 25$ \\
Type of refrigerant & - & $\mathrm{R} 410 \mathrm{~A}$ \\
\hline
\end{tabular}

Table 4. Technical data heat pump WI 45TU, manufactured by the Dimplex company.

\begin{tabular}{ccc}
\hline Parameter & Unit & Value \\
\hline Heating power (1 compressor operation, W10/W35) & $\mathrm{kW}$ & 25 \\
COP (1 compressor operation, W10/W35) & - & 6.2 \\
Heating power (2 compressor operation, W10/W35) & $\mathrm{kW}$ & 46.2 \\
COP (2 compressor operation, W10/W35) & - & 5.8 \\
Maximum flow temperature & ${ }^{\circ} \mathrm{C}$ & 62 \\
Heat source application limit (heating mode) & ${ }^{\circ} \mathrm{C}$ & $7 / 25$ \\
Type of refrigerant & - & $\mathrm{R} 410 \mathrm{~A}$ \\
\hline
\end{tabular}

Table 5. The temperatures in the selected locations.

\begin{tabular}{|c|c|c|c|c|c|c|}
\hline \multirow[b]{2}{*}{ The Location } & \multirow[b]{2}{*}{$\begin{array}{l}\text { The Climatic } \\
\text { Zone Number }\end{array}$} & \multicolumn{2}{|l|}{ According to [34] } & \multicolumn{2}{|c|}{ According to TWY } & \multirow[b]{2}{*}{ Bivalent Point } \\
\hline & & $\begin{array}{c}\text { The Designed } \\
\text { Outside } \\
\text { Temperature }\end{array}$ & $\begin{array}{l}\text { The Average } \\
\text { Annual Air } \\
\text { Temperature }\end{array}$ & $\begin{array}{l}\text { Minimum } \\
\text { Outside } \\
\text { Temperature }\end{array}$ & $\begin{array}{l}\text { Average Outdoor } \\
\text { Temperature } \\
\text { During the } \\
\text { Heating Season }\end{array}$ & \\
\hline & & $\begin{array}{l}t_{d}(\mathrm{a}) \\
\left({ }^{\circ} \mathrm{C}\right)\end{array}$ & $\begin{array}{c}t_{a} \\
\left({ }^{\circ} \mathrm{C}\right)\end{array}$ & $\begin{array}{l}t_{\min } \\
\left({ }^{\circ} \mathrm{C}\right)\end{array}$ & $\begin{array}{c}t_{a} \\
\left({ }^{\circ} \mathrm{C}\right)\end{array}$ & $\begin{array}{l}t_{b i v} \\
\left({ }^{\circ} \mathrm{C}\right)\end{array}$ \\
\hline Szczecin & I & -16 & 8.8 & -12.8 & 5.0 & -8 \\
\hline Poznań & II & -18 & 8.3 & -15.4 & 2.7 & -9 \\
\hline Łódź & III & -20 & 8.2 & -12.4 & 3.2 & -10 \\
\hline Białystok & IV & -22 & 6.9 & -17.5 & 2.2 & -11 \\
\hline Zakopane & $\mathrm{V}$ & -24 & 5.5 & -16.6 & 2.2 & -11.5 \\
\hline
\end{tabular}

(a) According to [34].

Below the bivalent point (cf. Table 5), ASHPs must be switched off, so another heat generator is necessary to supply heat at lower ambient temperatures. An oil boiler was assumed as the auxiliary heat generator whose heat generation and emissions are included in the analysis. The oil boiler was selected because a customer only pays for fuel consumption, and no contracted power costs are associated; it stems from a detailed cost analysis given in [35].

This analysis was performed on two variants related to temperature control in buffer tanks; the first variant assumed the temperature of water stored in the buffer tank was equal to the designed supply water temperature, while in the second variant, the temperature value in the buffer tanks resulted from a weather compensation. Three scenarios were analyzed: the first one was based on the current Polish energy mix presented by the national electrical energy provider PGE [36]; the second scenario presumed an increase in RES share up to $32 \%$ in electrical energy production, which is an aim outlined in the Energy policy of Poland until 2040 [32]; the last scenario was based on the electrical energetic mix that ensures GSHPs emit a lower amount of greenhouse gases than a condensing gas boiler. 


\subsection{The Low-Temperature Heat Reservoir}

The analysis firstly determined the temperatures of the lower temperature source in each type of the heat pumps analyzed regardless of the climatic zones. Since outside air is a heat source for an ASHP, the temperature continuously fluctuates depending on the weather conditions, while temperature variability in other heat sources, i.e., ground or groundwater, is significantly lower.

WSHPs take heat from a groundwater basin with a constant temperature whose value, in the Polish climatic conditions, determines the Kowalski equation [37]:

$$
t_{H}=t_{a}+A+g_{g}(H-h) \quad\left[{ }^{\circ} \mathrm{C}\right]
$$

where $t_{a}$ is the average annual air temperature in each climatic zone $\left({ }^{\circ} \mathrm{C}\right), A$ is a correction factor due to true altitude, $g_{g}$ is a geothermal gradient $(\mathrm{deg} / \mathrm{m}), H$ is a depth of a groundwater basin level (m), $h$ is the depth of the shallow zone (m); Table 6 shows the data set and the interim results for further modeling.

Table 6. The groundwater basins' data.

\begin{tabular}{cccccc}
\hline & $\begin{array}{c}\boldsymbol{A}^{\mathbf{( a )}} \\
\left.\mathbf{(}^{\circ} \mathbf{C}\right)\end{array}$ & $\begin{array}{c}g_{g}{ }^{(\mathbf{b})} \\
\mathbf{( d e g} / \mathbf{m})\end{array}$ & $\begin{array}{c}\boldsymbol{H}^{(\mathbf{c})} \\
\mathbf{( m )}\end{array}$ & $\begin{array}{c}\boldsymbol{h}^{(\mathbf{a})} \\
\mathbf{( m )}\end{array}$ & $\begin{array}{c}\boldsymbol{t}_{\boldsymbol{H}}{ }^{(\mathbf{d})} \\
\left({ }^{\circ} \mathbf{C}\right)\end{array}$ \\
\hline Szczecin & 0.82 & 43.4 & 38.6 & 16 & 9.8 \\
Poznań & 0.83 & 46.2 & 81.4 & 0 & 10.5 \\
Łódź & 0.87 & 41.7 & 175.3 & 108.8 & 10.3 \\
Białystok & 0.86 & 77.0 & 139.0 & 29 & 9.0 \\
Zakopane & 1.14 & 53.2 & $829.7^{(\mathrm{e})}$ & -149.0 & 24.7 \\
\hline
\end{tabular}

(a) According to [37], ${ }^{(b)}$ according to [38], ${ }^{(c)}$ according to [39], (d) the outcomes of Equation (1), ${ }^{(e)}$ according to [40].

In case of aggressive groundwater, a separating heat exchanger, as a method of protection against the negative effects of the groundwater, is necessary; this exchanger is installed in the front of the heat pump, which results in a brine temperature drop by about $2{ }^{\circ} \mathrm{C}$.

Ground temperature profile affects GSHP operation far greater. Further important parameters are: the type of an applied heat exchanger and its location depth, the depth of soil freezing and the geological structure, which is particularly important when a vertical exchanger is supposed to be installed. In the conduction of analysis, vertical closed loops with depths of $100 \mathrm{~m}$ were applied as heat exchangers. To determine the temperature profile in each climatic zone, the Baggs formula, adapted to the conditions of the northern hemisphere by Olesiewicz-Popiel et al. [41], was applied:

$t(z, \tau)=\left(t_{a}+\Delta t_{m}\right)-1.07 k_{v} A_{s} \exp \left(-0.00031552 z a^{-0.5}\right) \cos \left[\frac{2 \pi}{365}\left(\tau-\tau_{o}-0.018335 z a^{-0.5}\right)\right]\left[{ }^{\circ} \mathrm{C}\right]$

where $\tau$ is a day number in the year, $z$ is the depth $(\mathrm{m}), \Delta t_{m}$ is a difference between ground temperature below the shallow zone and average annual air temperature (deg), $k_{v}$ is a vegetation coefficient, $A_{s}$ is the amplitude of annual air temperature in every climatic zone (deg), $a$ is the soil thermal diffusivity $\left(\mathrm{m}^{2} / \mathrm{s}\right), \tau_{o}$ is the phase of the air temperature wave $(\mathrm{d})$ and $t_{a}$ is the average annual air temperature in each climatic zone $\left({ }^{\circ} \mathrm{C}\right)$; Table 7 shows the values substituted into Equation (3).

Formula (2) is integrated with respect to the depth, $z$, and divided by the heat exchanger length $z_{\max }=100 \mathrm{~m}$ to obtain the mean temperature in the ground for each hour of the heating season:

$$
\bar{t}(\tau)=\frac{\int_{0}^{z_{\max }} t(z, \tau) d z}{z_{\max }}
$$


Table 7. The data to the Baggs formula (Formula (2)).

\begin{tabular}{|c|c|c|c|c|c|}
\hline & $\begin{array}{l}\Delta t_{m}{ }^{(a)} \\
(\mathrm{deg})\end{array}$ & $\begin{array}{c}k_{v}^{(a)} \\
(-)\end{array}$ & $\begin{array}{l}A_{s}^{(a)} \\
\text { (deg) }\end{array}$ & $\begin{array}{c}a^{(a)} \\
\left(\mathrm{m}^{2} / \mathrm{s}\right)\end{array}$ & $\begin{array}{c}\tau_{o}{ }^{(a)} \\
\text { (d) }\end{array}$ \\
\hline Szczecin & & & 31.3 & & \\
\hline Poznań & & & 38.6 & & \\
\hline Łódź & 2.2 & 0.85 & 36.2 & $6 \cdot 10^{-7}$ & 22 \\
\hline Białystok & & & 40.3 & & \\
\hline Zakopane & & & 32.1 & & \\
\hline
\end{tabular}

(a) According to [41].

The brine temperature is lower by $5^{\circ} \mathrm{C}$ than the temperature obtained from Equation (3); this difference results from a use experience in the location.

\subsection{The Heating Curve and Bivalent Point}

Since weather conditions, particularly temperature, change the heat losses from a building, heating systems can supply heat at varying temperatures to meet the comfort requirements. This temperature is derived from a heating curve whose other inputs are the individual characteristics of a building, internal designed temperature, heat generator and its switch-off temperature. The last parameter is of particular importance for hybrid systems due to necessity of proper communication between two different heat sources; the temperature at which one heat generator switches off, simultaneously switching on an alternative heat generator, is called the bivalent point.

The heating curve was taken from the manufacturer guideline book [42] for the designed range of temperature and an assumption that heat losses at $15^{\circ} \mathrm{C}$ are covered by internal heat gains; it is plotted in Figure 1.

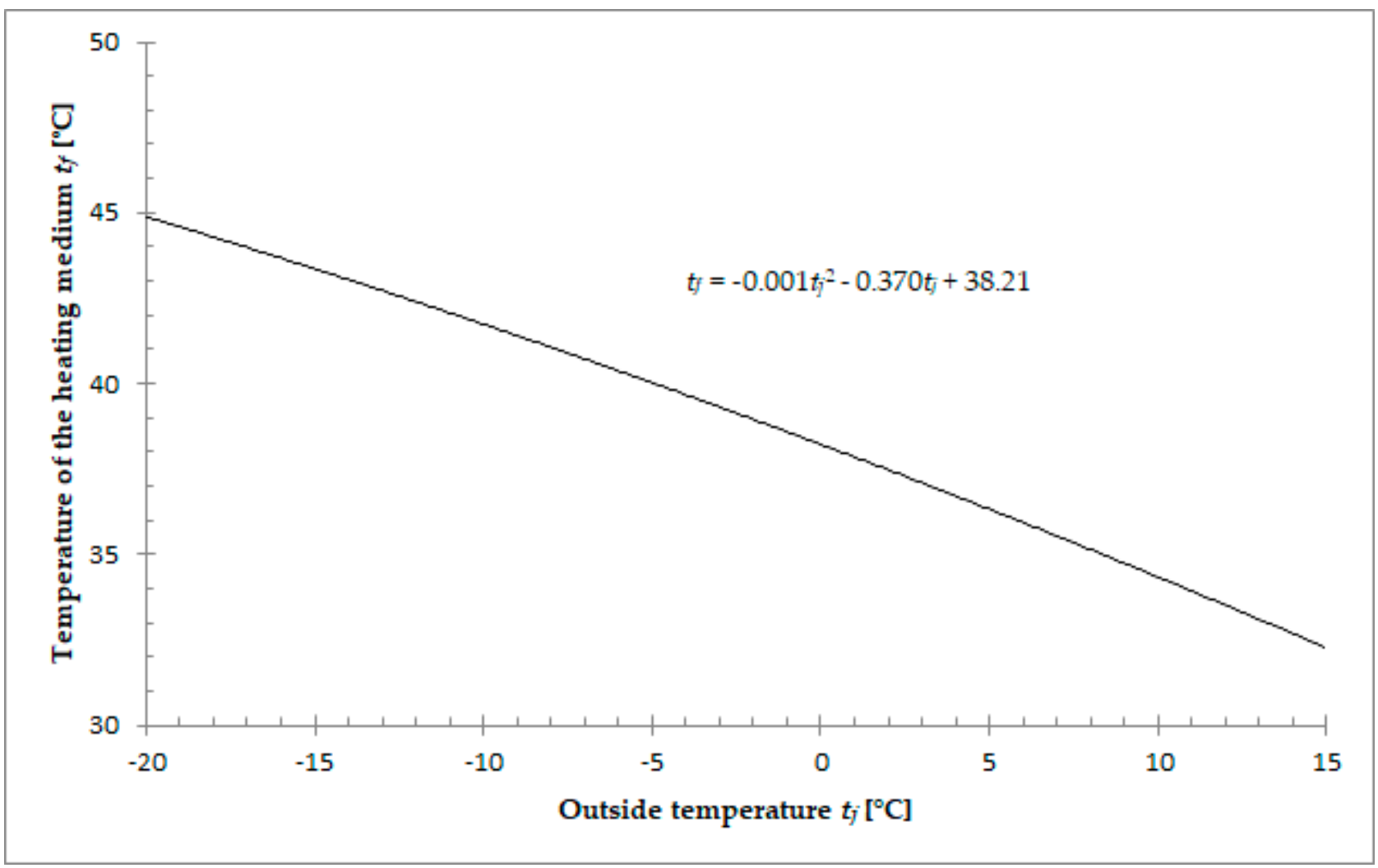

Figure 1. The heating curve applied in the heating system based on [42].

Since ASHPs take heat from outside air, opposing consequences ensue. As the outside temperature drops, less heat may be taken and in contrast, the heat losses go up. As heat 
sources supply less heat and heat demands simultaneously rise, more work must be done, which causes the COP value to decrease. An ASHP may work down to the temperature at which the energy conversion in it is viable; then, the oil boiler should come on. The bivalent point was determined in each climatic zone based on the manufacturer guidelines [42]; heating power distribution between two built-in compressors, the maximum heating system supply temperature, the heating system switch-off temperature and designed heat demand for space heating purposes were all taken into account.

\subsection{Seasonal Coefficient of Performance}

In order to determine the $\mathrm{SCOP}_{\text {net }}$ value, the value of the partial heat demand must be previously determined. For this purpose, the formula presented in the PN-EN 14825:201903 standard was used [43]:

$$
P_{h}\left(t_{j}\right)=\Phi_{i} \frac{\left(t_{i}-t_{j}\right)}{\left(t_{i}-t_{e}\right)} \quad[\mathrm{kW}]
$$

where $\Phi_{i}$ is the total designed heat load obtained using an algorithm from the standard PN-EN 12831-1:2017-08 [10], $t_{i}$ is the internal designed temperature that equals $20{ }^{\circ} \mathrm{C}, t_{j}$ is the external air temperature and $t_{e}$ is the external designed temperature.

Since every heat pump must be provided with a buffer tank with a capacity $V=1000 \mathrm{dm}^{3}$, the heat losses of the tank are included into the analysis. The efficiency of thermal energy storage $\eta_{t}=98 \%$. The designed temperature in the heat pump room is $20^{\circ} \mathrm{C}$. A heat pump switches on if the buffer tank temperature lowers by $4{ }^{\circ} \mathrm{C}$ below the heating curve temperature. The buffer tank heat losses are calculated from the formula:

$$
Q_{j}=\left[h_{j-1}-h\left(20^{\circ} \mathrm{C}\right)\right] \rho_{j-1} V\left(1-\eta_{t}\right)[\mathrm{kJ}],
$$

where:

$h_{j-1}$-specific enthalpy of water in the buffer tank in the previous hour $(\mathrm{kJ} / \mathrm{kg})$,

$h\left(20^{\circ} \mathrm{C}\right)$ - specific enthalpy of water in the buffer tank at the room temperature $(\mathrm{kJ} / \mathrm{kg})$, $\rho_{j-1}$-water density at the temperature in the previous hour $\left(\mathrm{kg} / \mathrm{m}^{3}\right)$.

Next, the temperature in the buffer tank was determined in the given hour:

$$
t_{t j}=t_{t j-1}-\frac{P_{h}\left(t_{j}\right) \cdot 3600+Q_{j}}{\rho_{j-1} V c_{p}}\left[{ }^{\circ} \mathrm{C}\right],
$$

where:

$t_{t j-1}$-water temperature in the buffer tank in the previous hour $\left({ }^{\circ} \mathrm{C}\right)$,

$c_{p}$-water specific heat $(\mathrm{kJ} /(\mathrm{kg} \cdot \mathrm{deg}))$.

The standard [43] also specifies the formula for $\mathrm{SCOP}_{\text {net }}$ computation:

$$
\mathrm{SCOP}_{\text {net }}=\frac{\sum_{j=1}^{n} h_{j}\left[P_{h}\left(t_{j}\right)\right]}{\sum_{j=1}^{n} h_{j}\left[\frac{P_{h}\left(t_{j}\right)}{\operatorname{COP}_{b i n}\left(t_{j}\right)}\right]}[-]
$$

where $h_{j}$ is number of bin hours occurring at external temperature $t_{j}$ in the heating season, $\mathrm{COP}_{\text {bin }}\left(t_{j}\right)$ is the COP value of the unit at external temperature $t_{j}$ and $j$ is a number of a temperature value (the temperature values are sorted in ascending order). Because 29th February occurs once per four years, the $h_{j}$ on this day was divided by four.

To evaluate the energetic viability of a heat pump in a heating season, a minimal value of SCOP was obtained from formula

$$
\mathrm{SCOP}_{\min }=\frac{\eta_{b}}{\eta_{t} \sum_{i=1}^{n} S_{i} \eta_{i}}[-]
$$


where $S_{i}$ is the share of fuel in domestic energy production, $\eta_{i}$ is the efficiency of the production and $\eta_{t}$ is the efficiency of the low voltage electricity supply; $\eta_{b}=106 \%$ is an energy performance factor of a condensing natural gas boiler; $\eta_{t}=79.2 \%$ is taken from [44]; other data are presented in Table 8.

Table 8. The Polish energy mix and the generation factors.

\begin{tabular}{|c|c|c|c|c|c|c|c|c|}
\hline \multirow[b]{2}{*}{ Fuel Type } & \multicolumn{4}{|c|}{$\begin{array}{l}\text { The Energy Market in } 2020 \\
\text { I Scenario }\end{array}$} & \multicolumn{4}{|c|}{$\begin{array}{l}\text { Projected Energy Market in } 2030 \\
\text { II Scenario }\end{array}$} \\
\hline & $\begin{array}{c}\text { Generation } \\
\text { Factor } \beta^{(a)} \\
(\mathrm{kg} / \mathrm{GJ})\end{array}$ & $\begin{array}{c}\text { Shares } \\
S^{(a)} \\
(\%)\end{array}$ & $\begin{array}{c}\text { Indirect } \\
\text { Emissions } \\
\qquad \beta_{i} \\
\\
(\mathrm{~kg} / \mathrm{GJ})\end{array}$ & $\begin{array}{c}\text { Efficiency } \\
\text { of Electrical } \\
\text { Energy } \\
\text { Production } \\
\text { From Heat } \\
\eta_{(\mathbf{b})} \\
(\%)\end{array}$ & $\begin{array}{c}\text { Generation } \\
\text { Factor } \beta^{(a)} \\
(\mathrm{kg} / \mathrm{GJ})\end{array}$ & $\begin{array}{c}\text { Shares } \\
S^{(a)} \\
(\%)\end{array}$ & $\begin{array}{c}\text { Indirect } \\
\text { Emissions } \\
\qquad \beta_{i} \\
\\
(\mathrm{~kg} / \mathrm{GJ})\end{array}$ & $\begin{array}{c}\text { Efficiency } \\
\text { of Electrical } \\
\text { Energy } \\
\text { Production } \\
\text { From Heat } \\
\eta^{(b)} \\
(\%)\end{array}$ \\
\hline & \multicolumn{8}{|c|}{$\mathrm{CO}_{2}$} \\
\hline $\begin{array}{l}\text { Bituminous } \\
\text { coal }\end{array}$ & 209.750 & 48.12 & $15.3^{c)}$ & 36 & 209.750 & 36.62 & $15.3^{c)}$ & 36 \\
\hline Lignite & 298.642 & 34.33 & $15.3^{c)}$ & 36 & 298.642 & 22.98 & $15.3^{c)}$ & 36 \\
\hline Natural gas & 85.356 & 8.20 & $5.0^{c)}$ & 34 & 85.356 & 8.20 & $5.0^{c)}$ & 34 \\
\hline Biomas & 87.203 & 2.90 & 0.0 & 36 & 87.203 & 2.90 & 0.0 & 36 \\
\hline Hydropower & 0.0 & 1.72 & 0.0 & - & 0.000 & 2.90 & 0.0 & - \\
\hline $\begin{array}{l}\text { Wind } \\
\text { turbines }\end{array}$ & 0.0 & 4.52 & 0.0 & - & 0.000 & 27.38 & 0.0 & - \\
\hline Other & \multicolumn{8}{|c|}{$\mathrm{SO}_{2}$} \\
\hline $\begin{array}{l}\text { Bituminous } \\
\text { coal }\end{array}$ & 0.147 & 48.12 & 0.010 & 36 & 0.147 & 36.62 & 0.010 & 36 \\
\hline Lignite & 0.261 & 34.33 & 0.013 & 36 & 0.261 & 22.98 & 0.013 & 36 \\
\hline Natural gas & 0.017 & 8.20 & 0.001 & 34 & 0.017 & 8.20 & 0.001 & 34 \\
\hline Biomas & 0.006 & 2.90 & 0.0 & 36 & 0.006 & 2.90 & 0.0 & 36 \\
\hline Hydropower & 0.0 & 1.72 & 0.0 & - & 0.000 & 2.90 & 0.0 & - \\
\hline $\begin{array}{l}\text { Wind } \\
\text { turbines }\end{array}$ & 0.0 & 4.52 & 0.0 & - & 0.000 & 27.38 & 0.0 & - \\
\hline Other & 0.0 & 0.20 & 0.0 & 35 & 0.000 & 0.20 & 0.0 & 35 \\
\hline & \multicolumn{8}{|c|}{$\mathrm{NO}_{x}$} \\
\hline $\begin{array}{l}\text { Bituminous } \\
\text { coal }\end{array}$ & 0.158 & 48.12 & 0.012 & 36 & 0.158 & 36.62 & 0.012 & 36 \\
\hline Lignite & 0.225 & 34.33 & 0.012 & 36 & 0.225 & 22.98 & 0.012 & 36 \\
\hline Natural gas & 0.064 & 8.20 & 0.004 & 34 & 0.064 & 8.20 & 0.004 & 34 \\
\hline Biomas & 0.053 & 2.90 & 0.0 & 36 & 0.053 & 2.90 & 0.0 & 36 \\
\hline Hydropower & 0.0 & 1.72 & 0.0 & - & 0.000 & 2.90 & 0.0 & - \\
\hline $\begin{array}{l}\text { Wind } \\
\text { turbines }\end{array}$ & 0.0 & 4.52 & 0.0 & - & 0.000 & 27.38 & 0.0 & - \\
\hline Other & 0.0 & 0.20 & 0.0 & 35 & 0.000 & 0.20 & 0.0 & 35 \\
\hline & \multicolumn{8}{|c|}{ PM } \\
\hline $\begin{array}{l}\text { Bituminous } \\
\text { coal }\end{array}$ & 0.011 & 48.12 & 0.0008 & 36 & 0.011 & 36.62 & 0.0008 & 36 \\
\hline Lignite & 0.008 & 34.33 & 0.0004 & 36 & 0.008 & 22.98 & 0.0004 & 36 \\
\hline Natural gas & 0.003 & 8.20 & 0.0002 & 34 & 0.003 & 8.20 & 0.0002 & 34 \\
\hline Biomas & 0.003 & 2.90 & 0.0 & 36 & 0.003 & 2.90 & 0.0 & 36 \\
\hline Hydropower & 0.0 & 1.72 & 0.0 & - & 0.000 & 2.90 & 0.0 & - \\
\hline $\begin{array}{l}\text { Wind } \\
\text { turbines }\end{array}$ & 0.0 & 4.52 & 0.0 & - & 0.000 & 27.38 & 0.0 & - \\
\hline Other & 0.0 & 0.20 & 0.0002 & 35 & 0.000 & 0.20 & 0.0002 & 35 \\
\hline
\end{tabular}




\subsection{Greenhouse Gases and Particulate Matter Emissions}

If a non-emission heat generator is driven by electricity, the emissions occur indirectly as a result of fossil fuel combustion during the production of this electricity. An amount of these emissions is inversely related to the share of non-emission power stations (e.g., solar, wind, or nuclear power plants). In the case of a bivalent system, apart from the indirect emissions due to ASHP work, the direct emissions, $\beta_{\text {oil }}$, caused by the operation of the oil boiler must also be computed; the algorithm checked whether the heat pump works at or beyond bivalent temperature, if yes $\varepsilon=1$, if not $\varepsilon=0$; for other heat pumps $\varepsilon=1$ in all the heating season; the emissions were computed from the formula [28]:

$$
E_{x}=\varepsilon \beta_{a g \times} \sum_{\mathrm{j}}^{\mathrm{n}} h_{j}\left[\frac{P_{h}\left(t_{j}\right)}{C O P_{b i n}\left(t_{j}\right)}\right]+(1-\varepsilon) \beta_{\mathrm{oil}} \sum_{\mathrm{j}}^{\mathrm{n}} h_{j} \frac{P_{h}\left(t_{j}\right)}{\eta_{b}}\left[\mathrm{~kg}_{\mathrm{x}} / \mathrm{a}\right]
$$

where $\beta_{a g}$ is an aggregate greenhouse gas generation factor which accounts for direct and indirect emissions amid electrical energy production and shares of the fuels in it (presented in Table 5); $\eta_{b}=86.9 \%$ is the efficiency of the bivalent heat generator.

Since $C O P_{b i n}$ is not the same function of the temperature for each heat pump, to compare the generation factors between the heat pumps and a condensing gas boiler, a comparative generation factor, $\beta_{c}$, was computed as follows:

$$
\beta_{\mathrm{c}}=\frac{E_{x}}{\sum_{\mathrm{j}}^{\mathrm{n}} h_{j} P_{h}\left(t_{j}\right)_{x}}\left[\mathrm{~kg}_{\mathrm{x}} / \mathrm{GJ}\right]
$$

Since some levels of indirect emissions, even in the second scenario, were higher than emissions from the condensing gas boiler, further modification in the Polish energy sector is necessary, yet the larger contribution of RES in Polish energy mix is not assumed in the policy [32]. Thus, this sector should be modified in an alternative way, so the authors propose the replacement of coal-based steam generators with natural gas-fired gas turbines, which is the third scenario; the proposed shares of the fuels are presented in Table 9.

Table 9. The energy mix assumed in the third scenario.

\begin{tabular}{ccc}
\hline Fuel Type & Shares & \multicolumn{2}{c}{$\begin{array}{c}\text { Efficiency of Energy Production From Heat } \\
\text { (a) }\end{array}$} \\
& S & $(\%)$ \\
Bituminous coal & 4.00 & 36 \\
Lignite & 0.00 & 36 \\
Natural gas & 8.20 & 34 \\
Natural gas-fired gas & 55.60 & $42(\mathrm{~b})$ \\
turbine & 2.90 & 36 \\
Biomas & 1.72 & - \\
Hydropower & 27.38 & - \\
Wind turbines & 0.20 & 35 \\
Other &
\end{tabular}

(a) According to [45], ${ }^{(b)}$ according to [46].

\section{Results}

$\mathrm{SCOP}_{\text {net }}$ outcomes achieved from Equation (7) for every calculation variant are presented in Table 10. SCOP $\min$ values calculated from Equation (8) are equal to 3.36, 2.46, and 2.32 for the first, second, and third scenario, respectively. The ground temperature dropped by $1.89^{\circ} \mathrm{C}$ because of the thermal energy use (cf. [27]), which caused lower $\mathrm{SCOP}_{\text {net }}$ values, which are shown in the column entitled "GSHP (dropped temp.)"; this lowering was by about $5 \%$.

Table 10 shows that the least efficient ASHPs did not reach the required $\mathrm{SCOP}_{\min }$ value in the first scenario under control to a constant temperature in the buffer tank; in other cases, the heat pumps were energetically viable. Though Łódź is located in the third 
climatic zone, the SCOP net of ASHP and GSHP were higher than in Poznan, which is in the warmer second zone; this was caused by the higher temperatures of TMY in Łódź than in Poznan, which resulted from long-term measurements, as shown in in Table 5. Taking weather data from TMY means that other results may not be presented in either ascending or descending order with regard to the climatic zones.

Table 10. The results of (SCOP net) obtained from Equation (7).

\begin{tabular}{ccccccccccc}
\hline & \multicolumn{3}{c}{ At a Constant Temperature in the Buffer Tank } & \multicolumn{3}{c}{ With Changed Temperature in the Buffer Tank } \\
Location & ASHP & GSHP & $\begin{array}{c}\text { GSHP } \\
\text { Dropped } \\
\text { Temp.) }\end{array}$ & WSHP & $\begin{array}{c}\text { WSHP + } \\
\text { SHE }\end{array}$ & ASHP & GSHP & $\begin{array}{c}\text { GSHP } \\
\text { (Dropped } \\
\text { Temp.) }\end{array}$ & WSHP & WSHP + \\
SHE
\end{tabular}

WSHPs are highly efficient heat pumps with the highest SCOP net values in each zone; they maintains their superiority even with additional SHE in some cases, which is directly related to the heat source temperature. In the case of GSHPs, wherein vertical heat exchangers are used which transfer heat from the ground, the temperature changes caused by the weather conditions were delayed and depended on the time of year. Meanwhile, WSHPs are supplied with heat from deep groundwater basins where the temperature is almost constant and slightly higher than the mean ground temperature because of the lack of a shallow zone impact on the resultant temperature.

$\mathrm{SCOP}_{\text {net }}$ fell in relation to average outside temperature for ASHPs and GSHPs, while

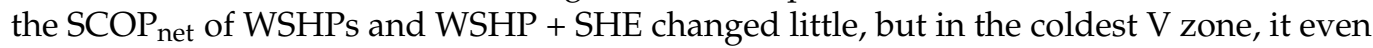
considerably increased. The outside temperature affected heat pump performance in two ways: heat source and heat sink temperature values; although its effect on the heat sink temperature was cushioned by the heating curve, it yielded different supply temperature variations in every town. The impact of weather conditions on heat source operation was much more diversified; they affected ASHPs directly, as the outside air is a heat reservoir in this case; their impact on ground temperature was deadened by the thermal resistance of the ground, but below the shallow zone, the temperature was constant and only depended on the mean yearly outside temperature and a cover of the ground; the influence on the groundwater basin temperature was assumed to be constant throughout year. The growing depth of the ground heat exchanger and the groundwater basin increased the temperature and SCOP ${ }_{\text {net }}$; hence, Table 10 Shows a considerable increase in SCOP net value for WSHPs in the coldest V zone, where the groundwater basin is very deep (cf. Table 3).

Regardless of the considered heat source, the SCOP net value was lower for the installations that operated at a constant temperature value in the buffer in comparison to those controlled along the heating curve, which is due to the temperature in the condenser. In the first case, this temperature was maintained at the designed value throughout the entire period of operation in the heating season, i.e., the maximum operating value, so pressure on the discharge side was also maximal and the compressor consumed the most work. In the second case, the compressor power modulated depending on the current heat demand resulting from the weather conditions. Since the outside temperatures were usually higher than the designed outside temperature, the weather compensator adjusted lower supply temperature, so the compressor worked up to the lower pressure, which translated into lower power consumption.

Figure 2 summarizes the results of greenhouse gas emissions obtained from Equation (9) in each climatic zone during the heating season for the first and second scenarios. 


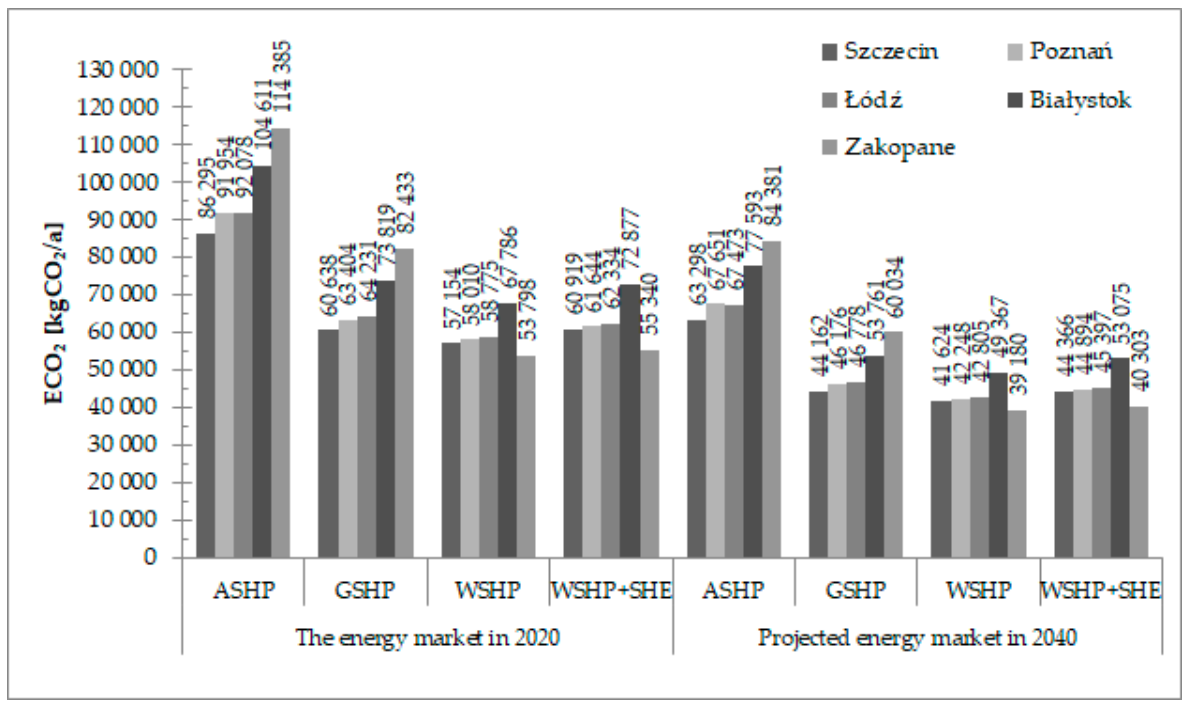

(a)

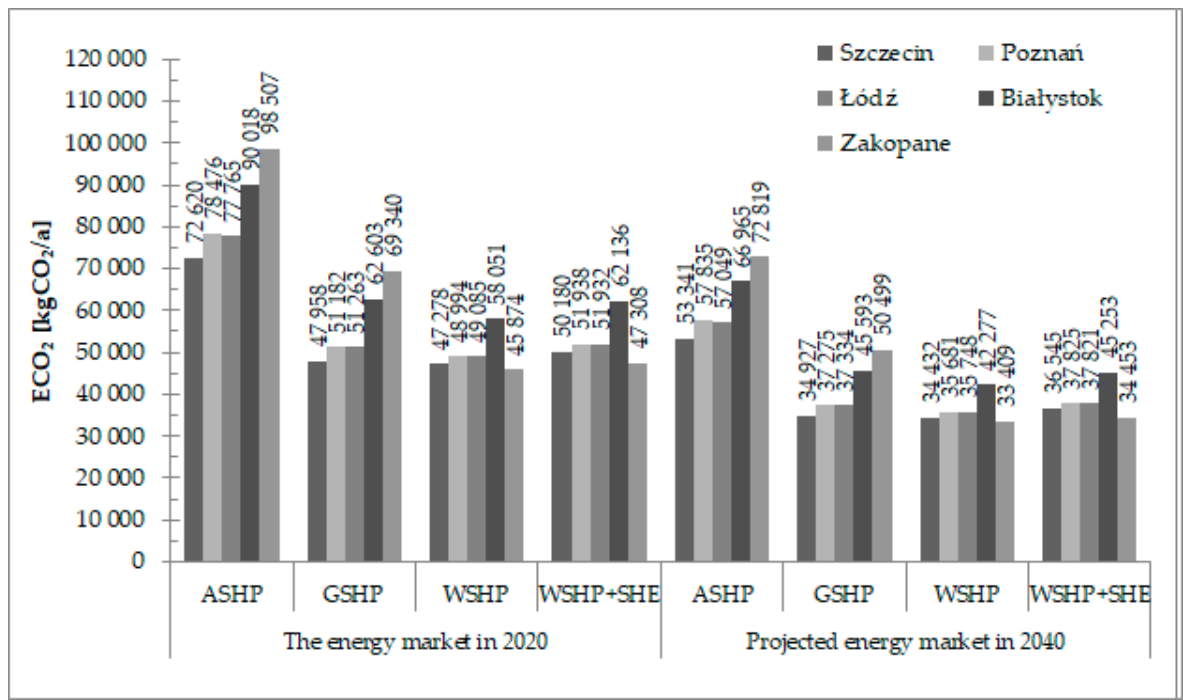

(b)

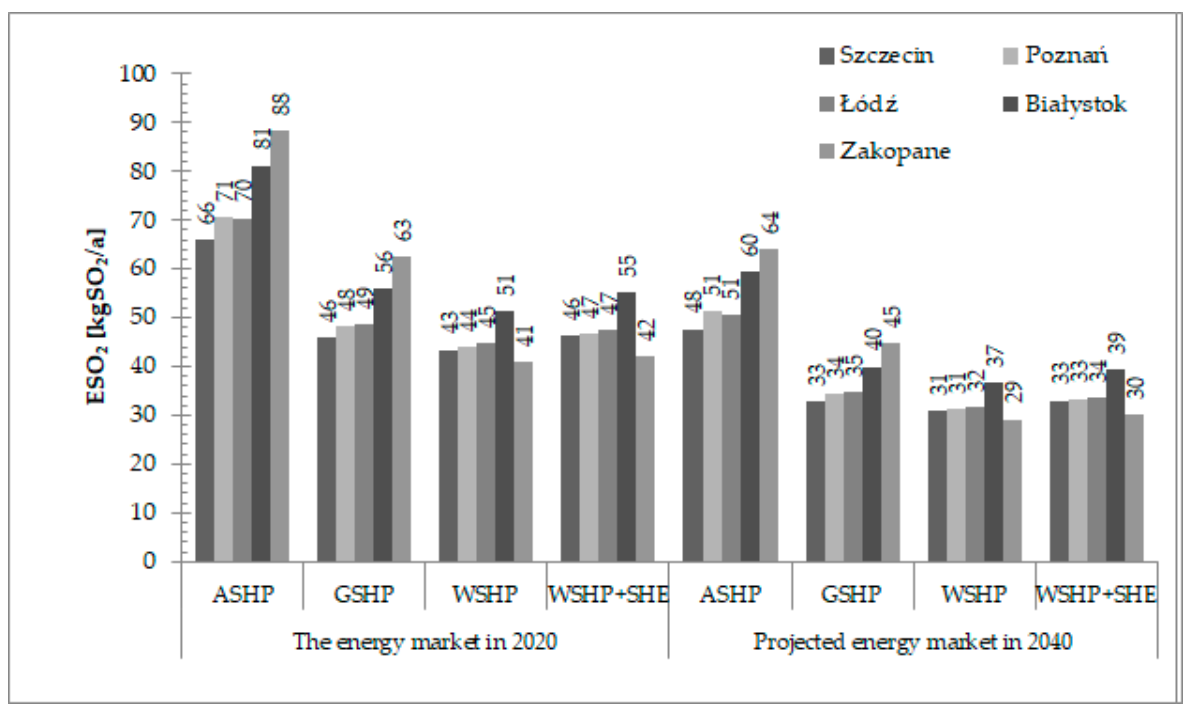

(c)

Figure 2. Cont. 


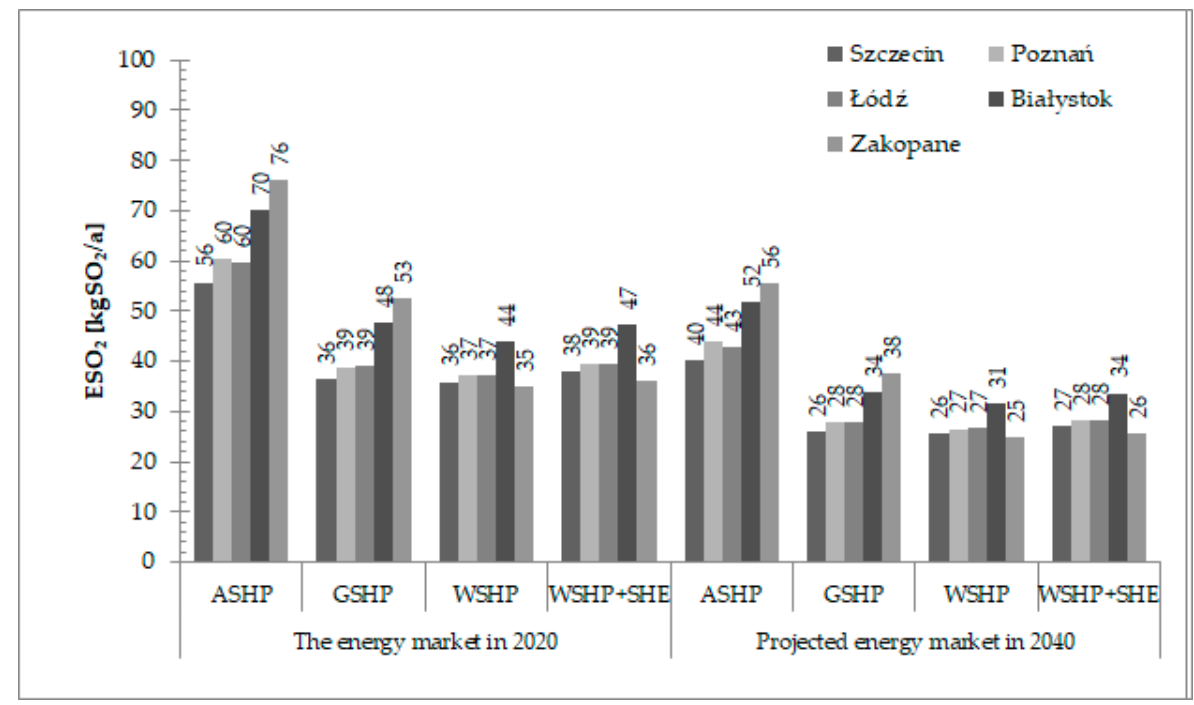

(d)

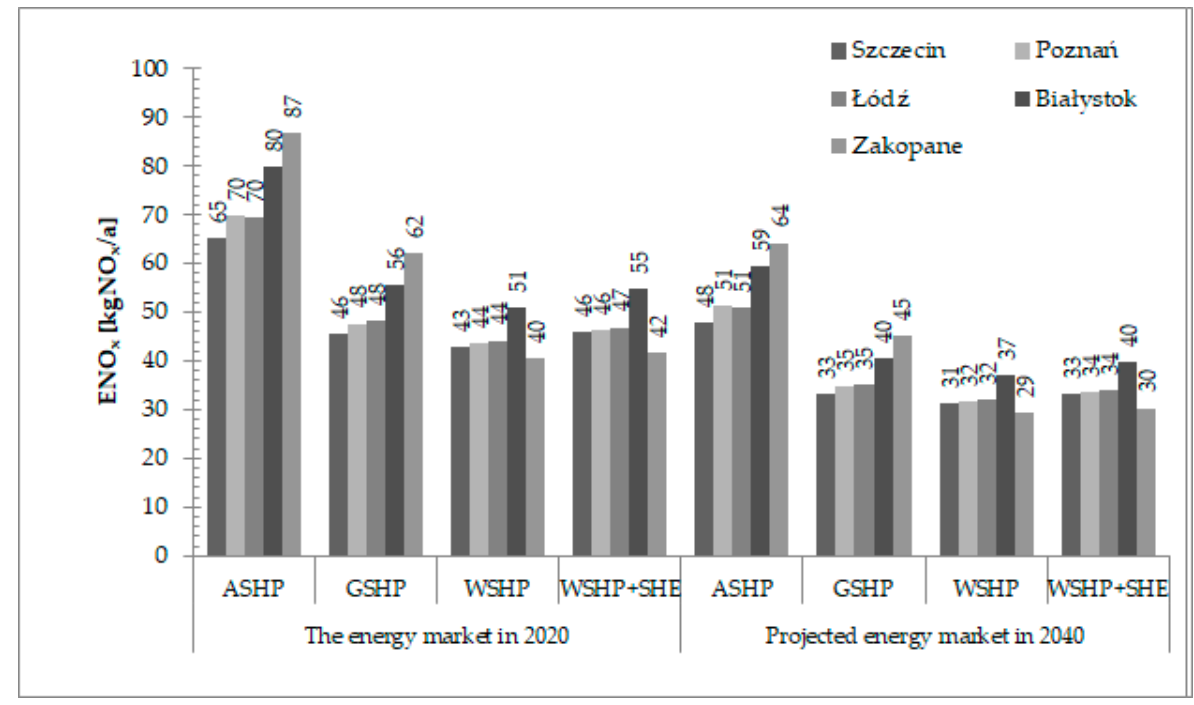

(e)

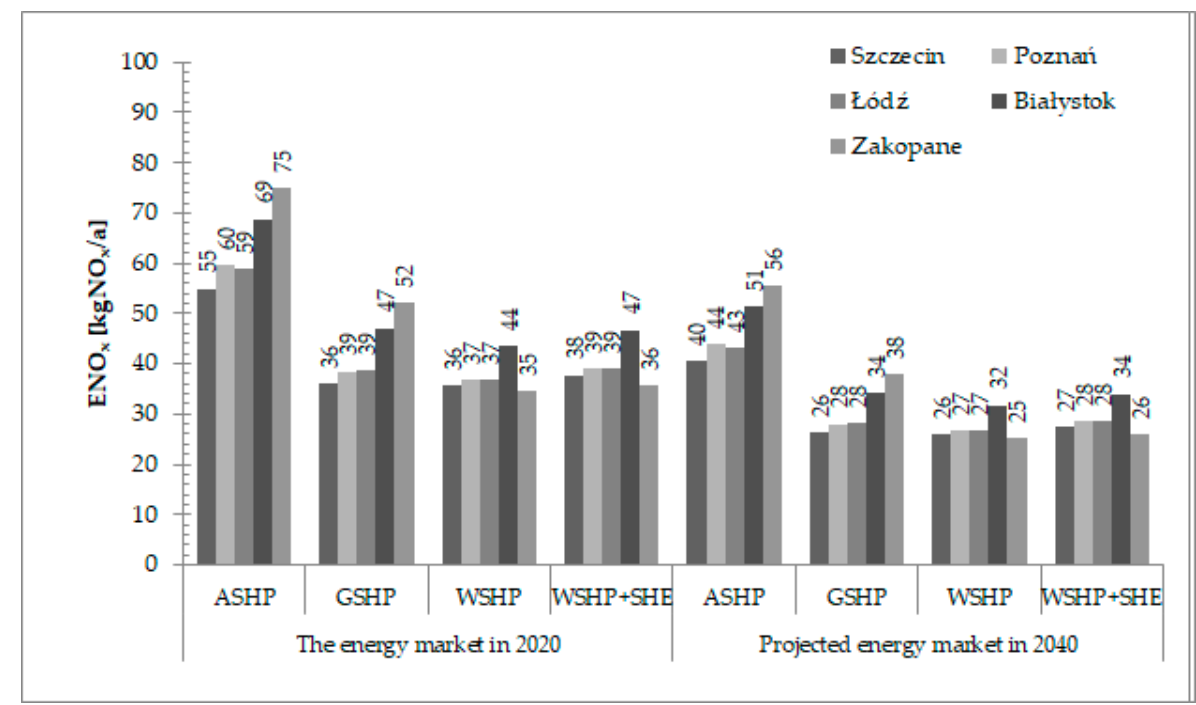

(f)

Figure 2. Cont. 


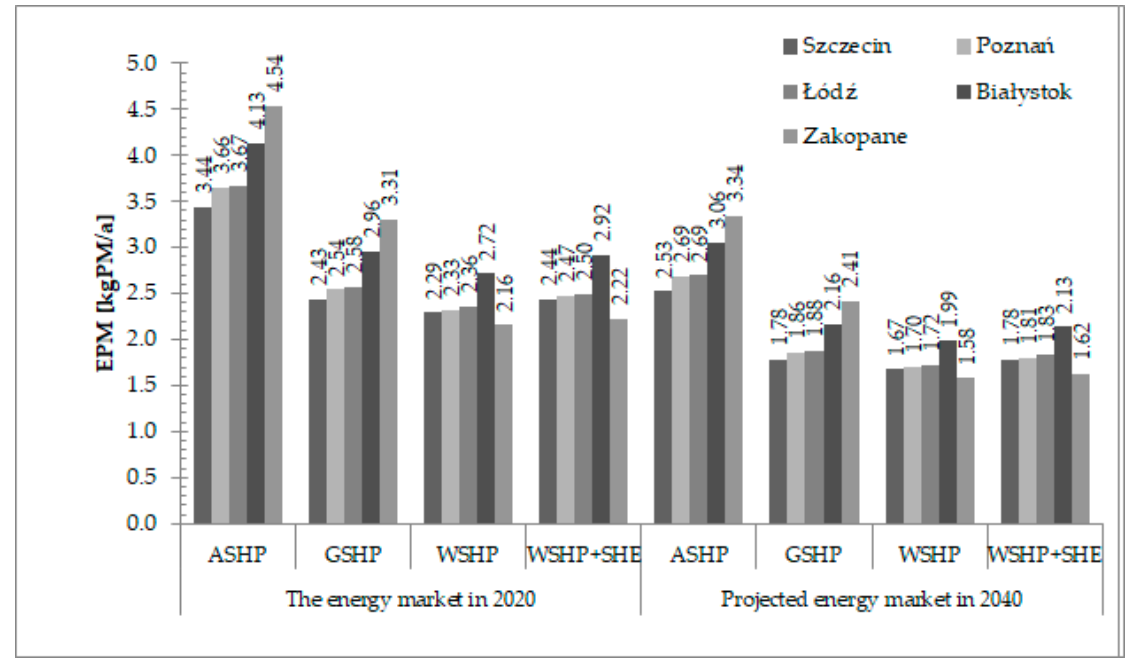

$(\mathrm{g})$

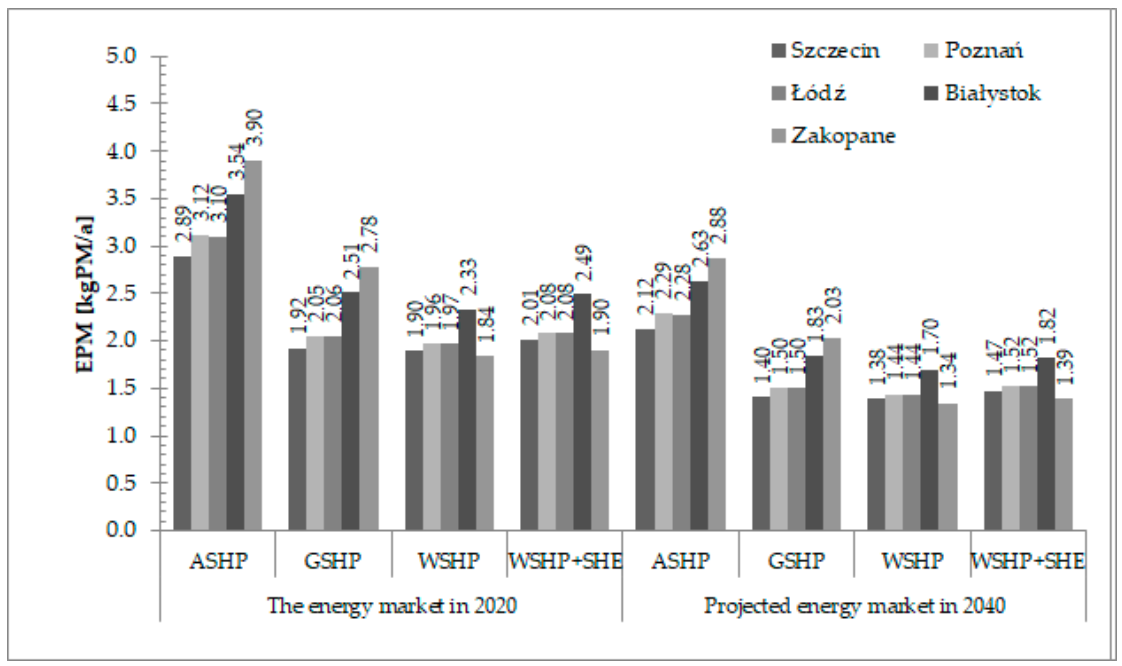

(h)

Figure 2. Greenhouse gases and particulate matter emissions for specific locations: (a) carbon dioxide emissions at a constant temperature in the buffer tank; (b) carbon dioxide emissions with changed temperature in the buffer tank; (c) sulfur dioxide emissions at a constant temperature in the buffer tank; (d) sulfur dioxide emissions with changed temperature in the buffer tank; (e) nitrogen oxide emissions at a constant temperature in the buffer tank; (f) nitrogen oxide emissions with changed temperature in the buffer tank; (g) PM emissions at a constant temperature in the buffer tank; (h) PM emissions with changed temperature in the buffer tank.

If the second scenario was put into practice, the emissions would be reduced by circa one fourth. GSHPs, WSHPs and WSHP + SHE would emit less carbon dioxide by $27.2 \%$. Slightly lower reductions would be seen for ASHPs: $26.6 \%, 26.4 \%, 26.7 \%, 25.8 \%$, and $26.2 \%$ for the towns. Sulfur dioxide emissions would be less by $28.7 \%$ for GSHPs, WSHPs and WSHP + SHE, and they would be reduced by: $27.9 \%, 27.6 \%, 28.0 \%, 26.7 \%$ and $27.3 \%$ for ASHPs. Nitrogen oxide emissions would be cut by $27.2 \%$ for GSHPs, WSHPs, and WSHP + SHE, and for ASHPs, they would be cut by $26.6 \%, 26.3 \%, 26.7 \%, 25.5 \%$ and $26.0 \%$. PM emissions would be limited by $26.9 \%$ for GSHPs, WSHPs, and WSHP + SHE; their limitations would be: $26.6 \%, 26.4 \%, 26.6 \%, 26 \%$ and $26.3 \%$ for ASHPs.

In comparison with the first variant, the variant with changed temperature in the buffer reduced emissions by 13.3-20.9\%. The smallest reductions were for ASHPs, followed by WSHPs, while the biggest reductions were for GSHP. 
Inasmuch as ASHPs have to be switched off below the bivalent point, the alternative heat generator emits directly greenhouse gases as part of the indirect emissions, so the effect of decreased emissions amid domestic energy production is counteracted by a fossil fuel combustion in the location; to put it more simply, emissions reduction is lower by ca. $5 \%$ in comparison to other heat pumps.

The results of the emissions of distinct types of greenhouse gases indicate that its amount inversely corresponds to the $\mathrm{SCOP}_{\text {net }}$ value, which results from the fact that the amount of electricity consumed decreases as COP increases. The ground temperature drop due to the consumption of thermal energy increases the emissions by ca. $5 \%$.

Figure 3 shows the results of Equation (10), where the outcomes for the heat pumps are plotted in the form of bars, but the reference value for a condensing gas boiler is plotted as a horizontal line.

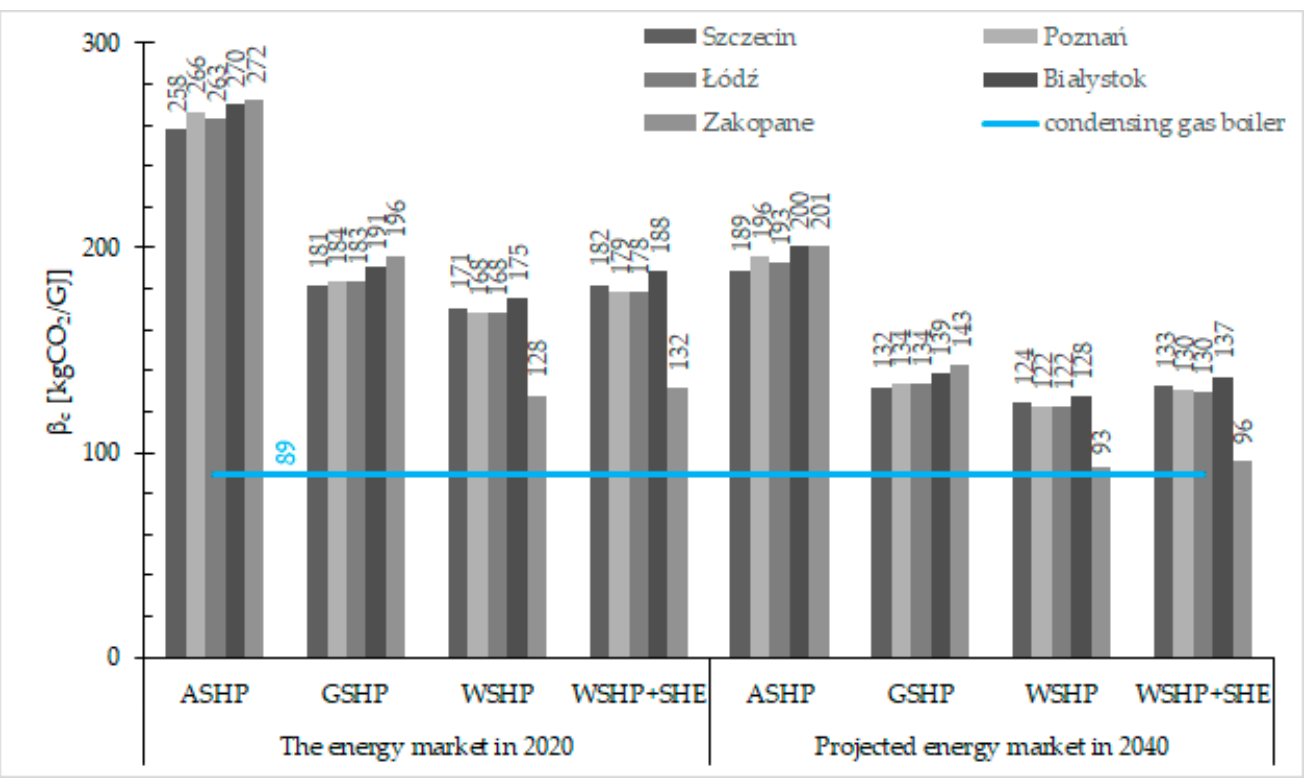

(a)

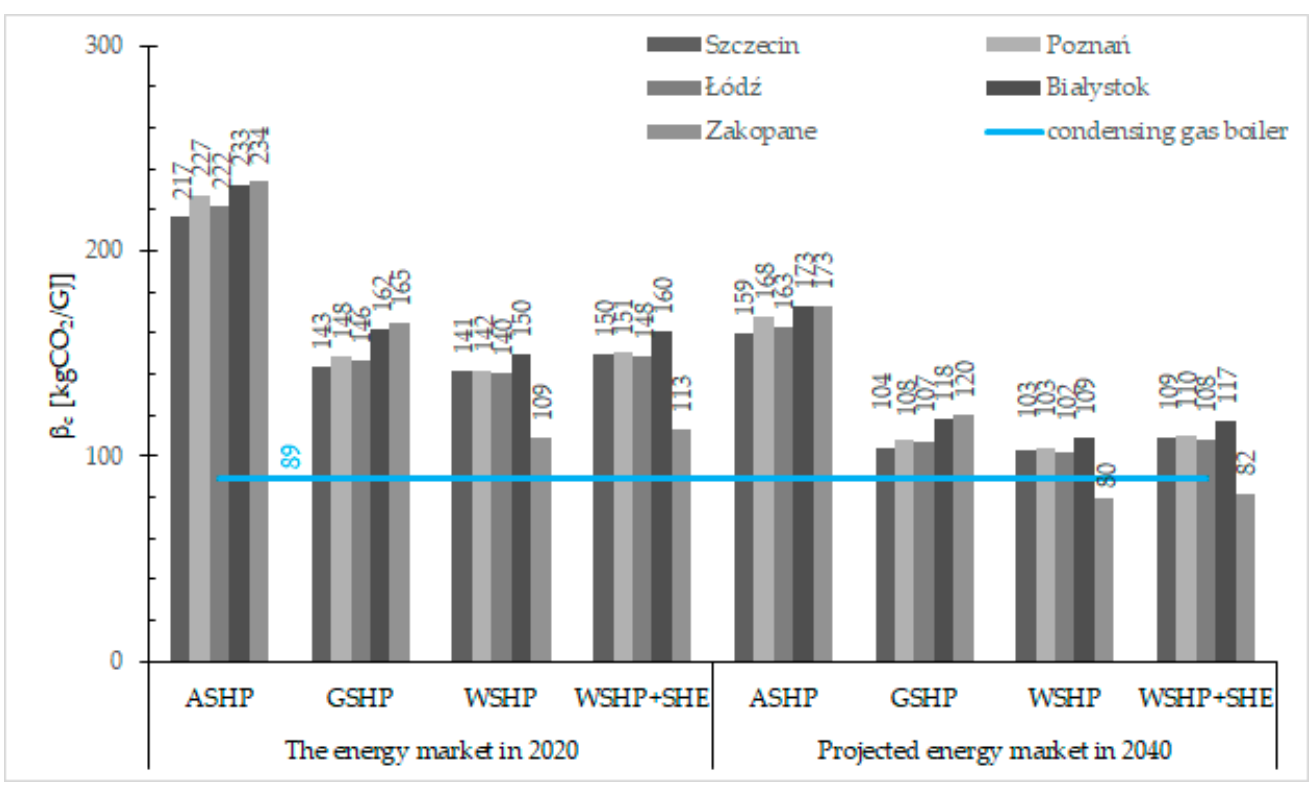

(b)

Figure 3. Cont. 


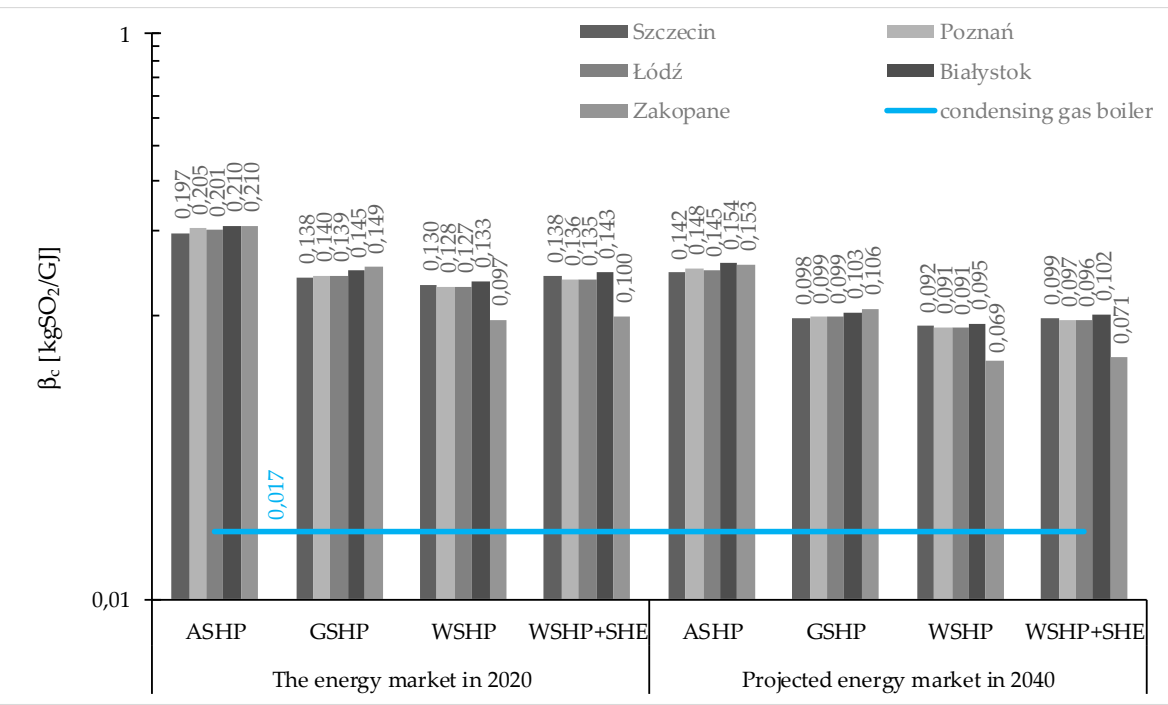

(c)

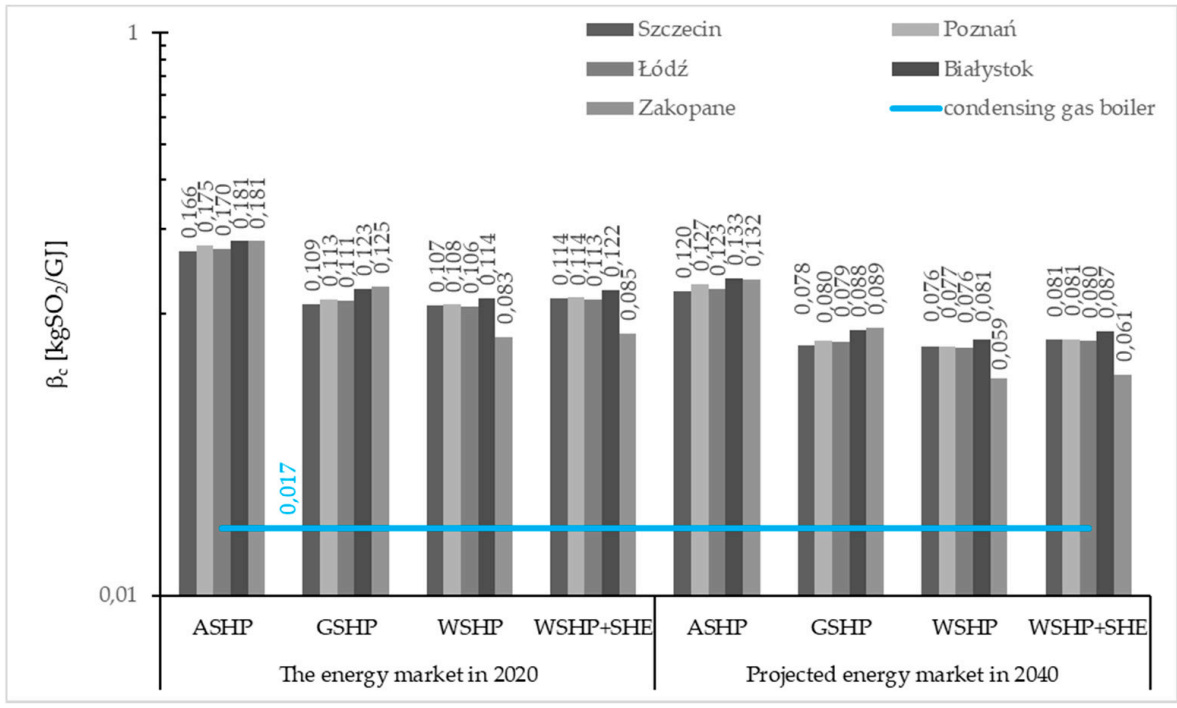

(d)

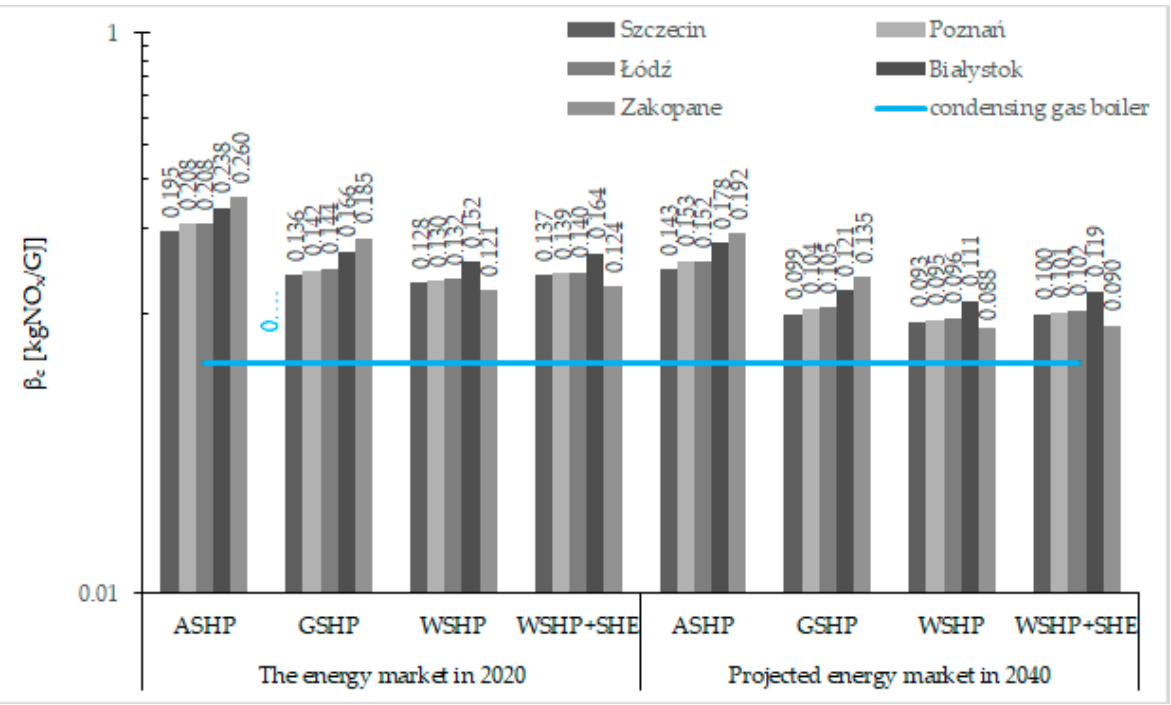

(e)

Figure 3. Cont. 


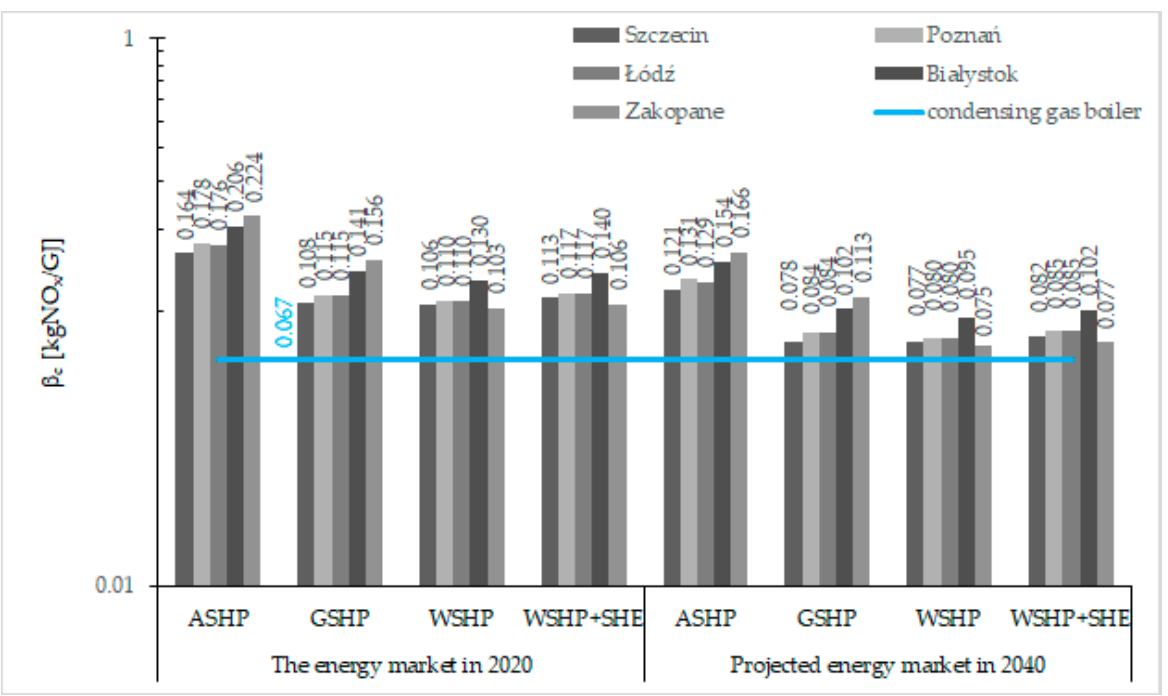

(f)

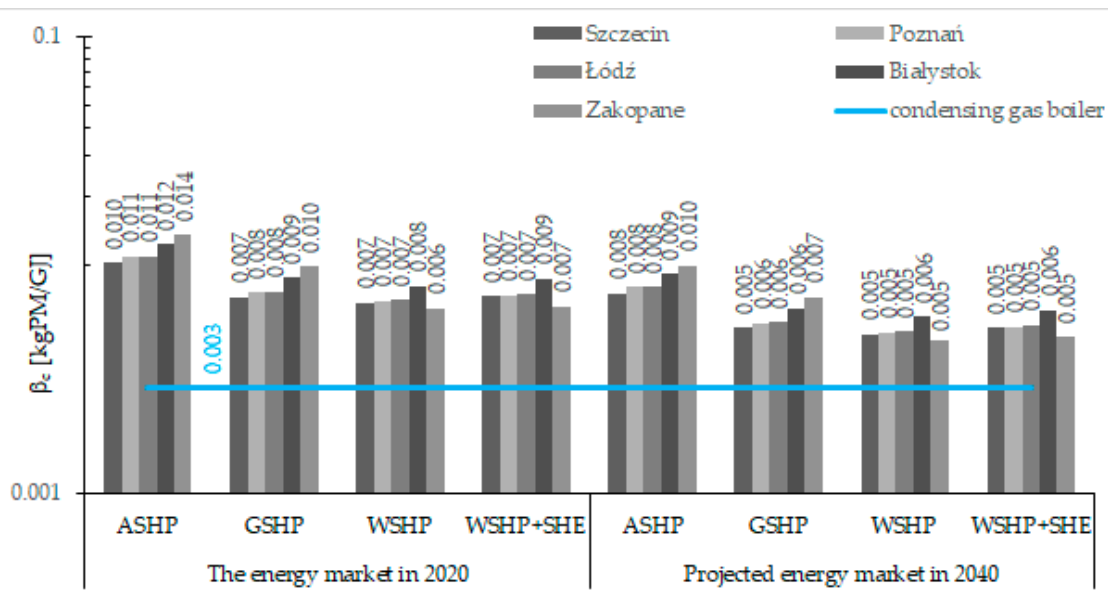

$(\mathbf{g})$

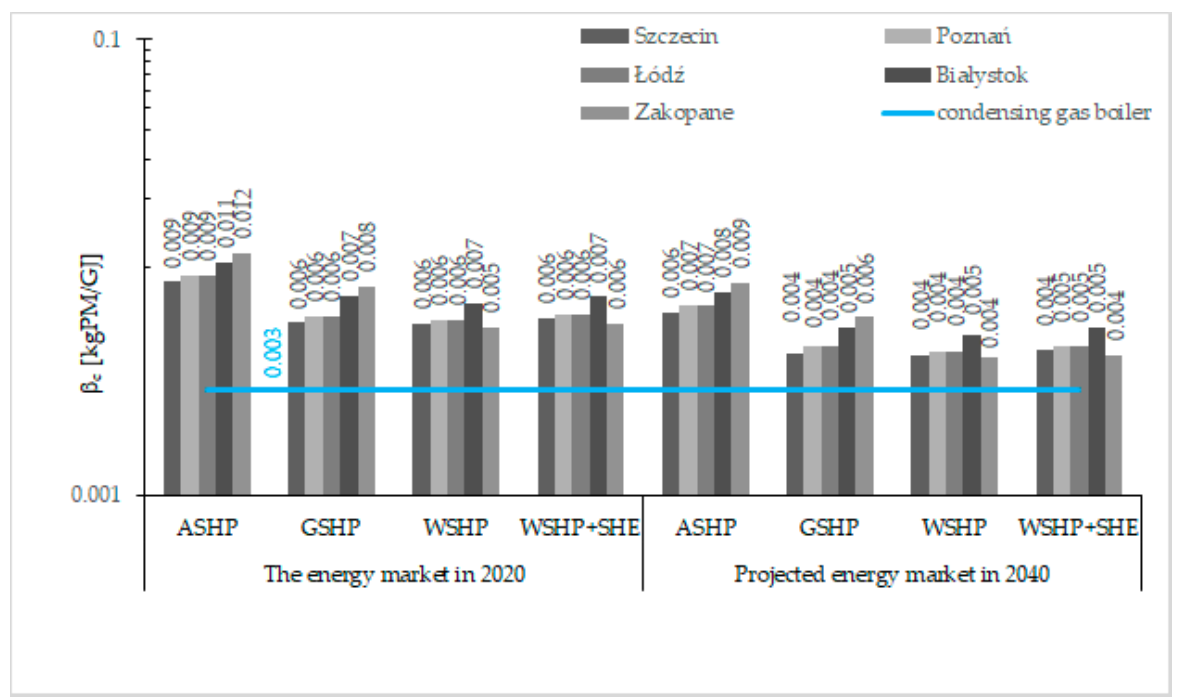

(h)

Figure 3. Unit emissions of greenhouse gases and particulate matter for the heat pumps in the specific locations as well as unit emissions of condensing gas boiler as the reference level: (a) carbon dioxide 
emissions at a constant temperature in the buffer tank; (b) carbon dioxide emissions with changed temperature in the buffer tank; (c) sulfur dioxide emissions at a constant temperature in the buffer tank; (d) sulfur dioxide emissions with changed temperature in the buffer tank; (e) nitrogen oxide emissions at a constant temperature in the buffer tank; (f) nitrogen oxide emissions with changed temperature in the buffer tank; (g) PM emissions at a constant temperature in the buffer tank; (h) PM emissions with changed temperature in the buffer tank.

Figure 3 shows that $\mathrm{CO}_{2}$ emissions from the WSHP in the second variant in Zakopane would be less than from the condensing gas boiler if the second scenario was realized, which also includes an effect of $20.8 \%$ electrical power transfer losses. In other words, the indirect emissions levels are 1.26 times higher because of the transfer losses.

To reduce all emissions from the heat pumps below the condensing gas boiler level in the whole of Poland, the Polish energy mix must vary very substantially. The results of the variation suggested in Table 9 are shown in Figure 4.

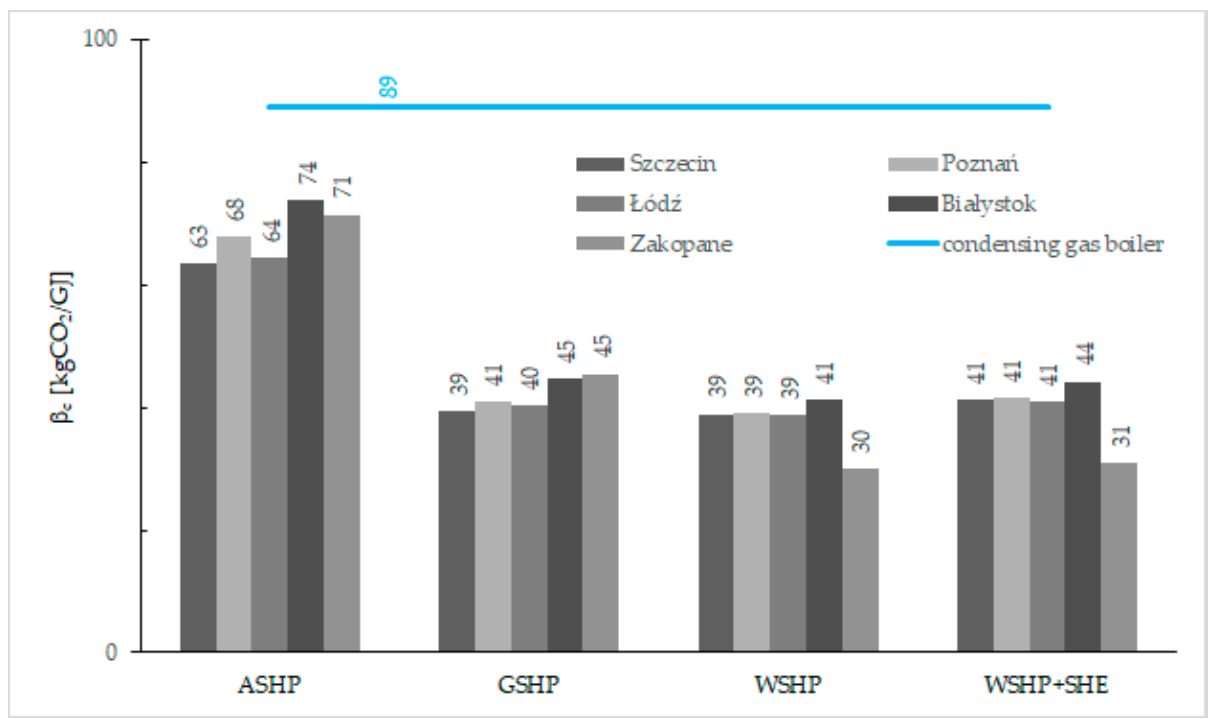

(a)

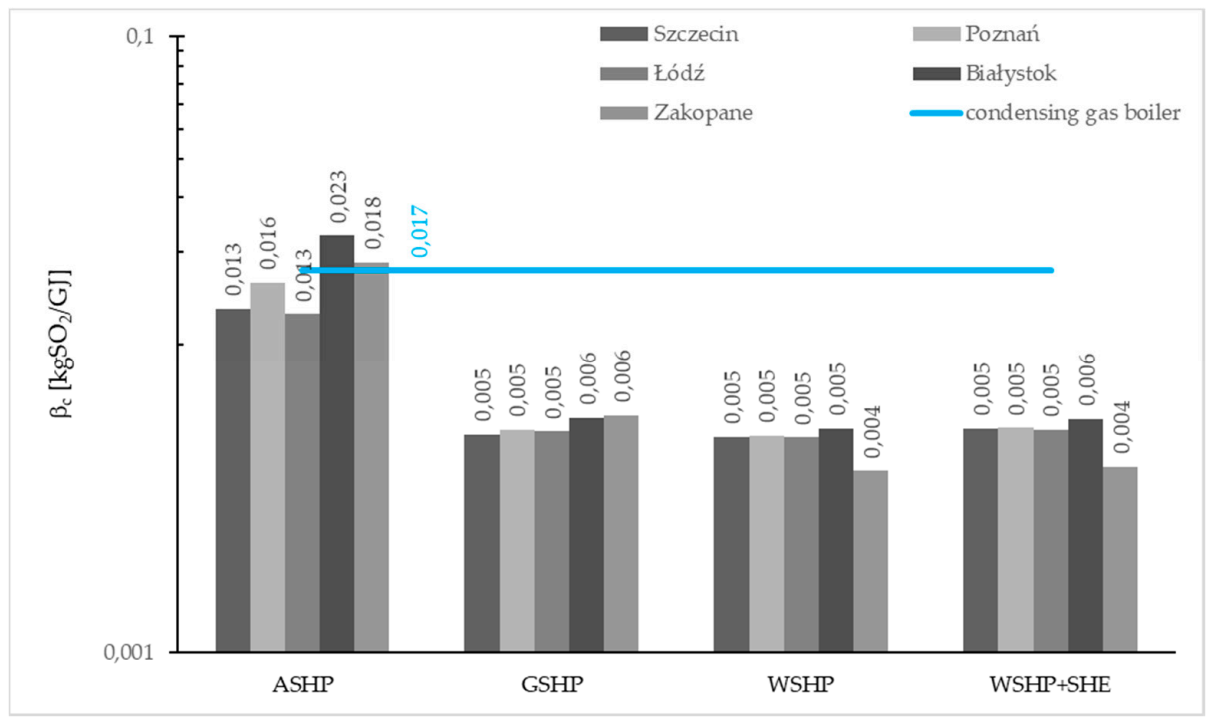

(b)

Figure 4. Cont. 


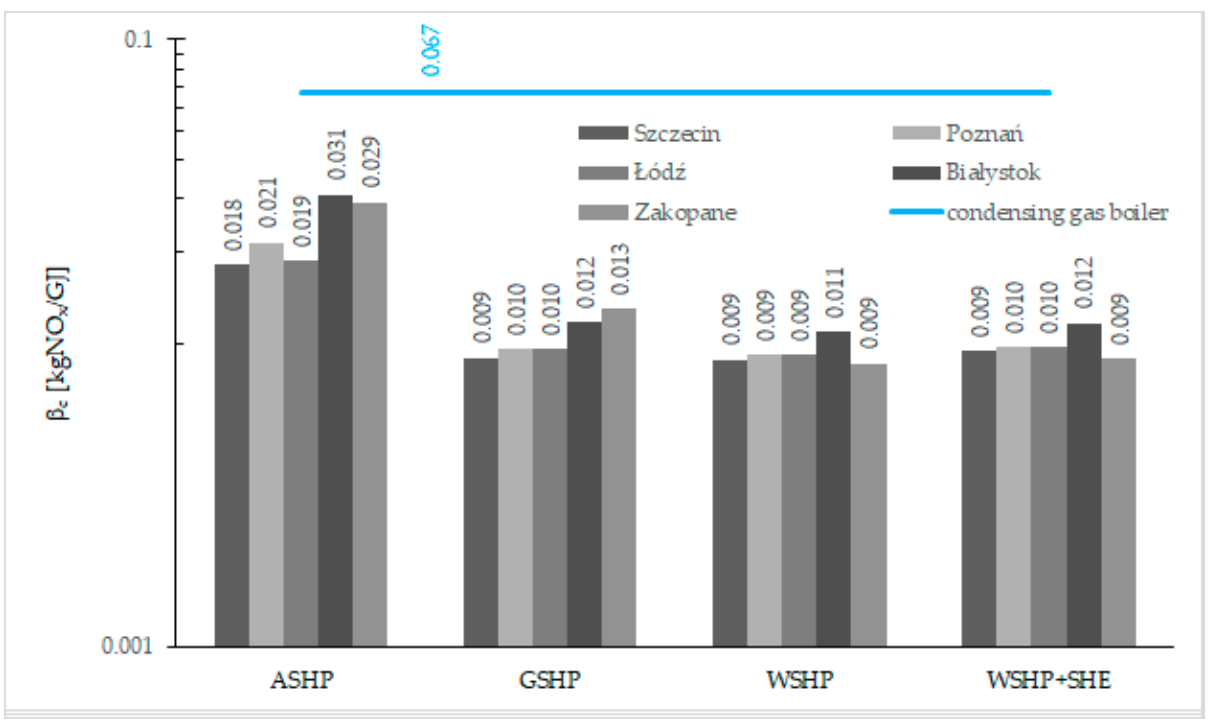

(c)

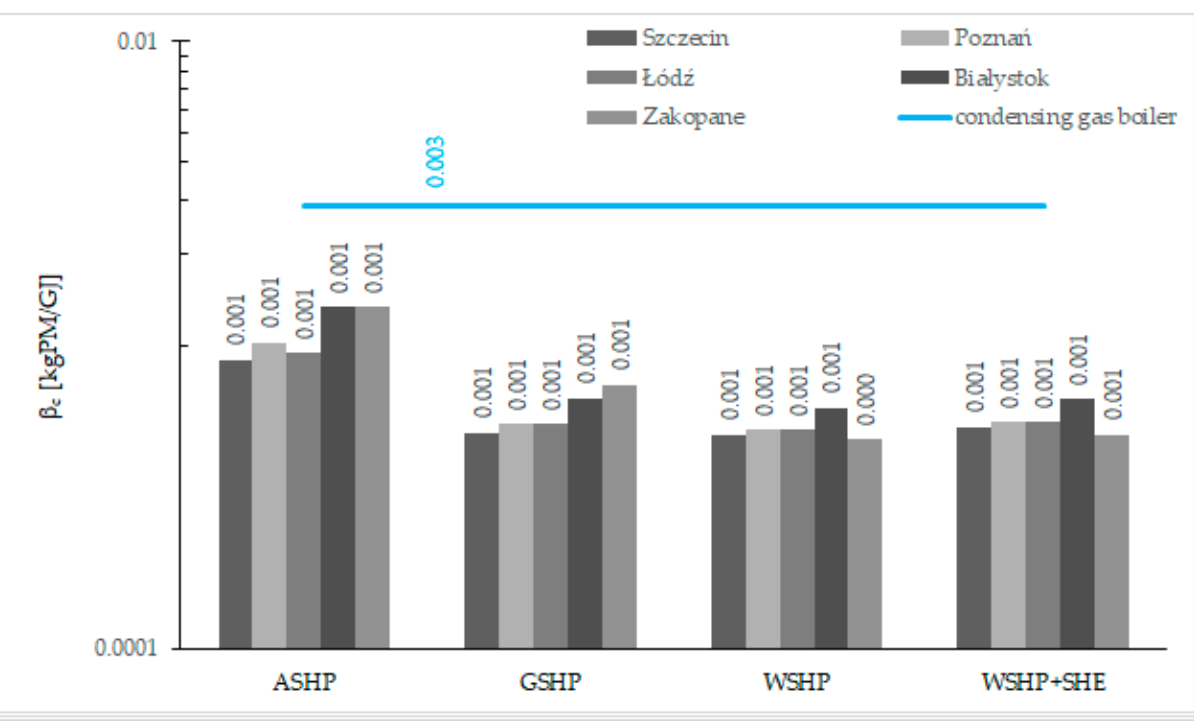

(d)

Figure 4. The outcomes for 3rd scenario; unit emissions of greenhouse gases and particulate matter for the heat pumps in the specific locations determined for the variant with changed temperature in the buffer tank as well as unit emissions of condensing gas boiler as a reference level: (a) carbon dioxide; (b) sulfur dioxide; (c) nitrogen oxide; (d) particulate matter.

Figure 4 shows that enormous changes to the Polish energy mix result in desirable outcomes; only the emission levels of nitrogen oxide caused by ASHP operation in the fourth climatic zone would be slightly higher than those of condensing gas boilers. The highest emissions levels in the third scenario relate to the ASHP in Białystok; if we divide the emissions levels in Białystok by the reference level, we obtain ratios that indicate the amount of emissions in relation to condensing gas boilers: $0.83,1.09,0.463$ and 0.462 for $\mathrm{CO}_{2}, \mathrm{SO}_{2}, \mathrm{NO}_{\mathrm{X}}$ and $\mathrm{PM}$, respectively. Thus, reductions in $\mathrm{SO}_{2}$ emissions needs the biggest effort, followed by $\mathrm{CO}_{2}$, whilst reductions in $\mathrm{NO}_{X}$ and $\mathrm{PM}$ emissions seems to be relatively easy to achieve.

Both absolute and unit emissions caused by GSHPs, WSHPs, and WSHP + SHE in the third scenario are correlated with the weather conditions and temperature of the lowtemperature heat reservoir. Meanwhile, the unit emissions caused by ASHPs are also affected by a share of the bivalent heat generator in the heat production; these shares are 
$2.06 \%, 3.02 \%, 1.80 \%, 5.55 \%$, and $3.92 \%$ in the climatic zones, respectively. This bigger share raises an emission level, but greater $\mathrm{SCOP}_{\text {net }}$ reduces this level. That is, these two factors exert contrasting effects, which causes the emission level from the ASHP in Łódź to be lower than in Poznan and slightly higher than in Szczecin, but the emissions in Zakopane are lower than in Białystok, and each of these three former levels are lower than any of the two latter.

\section{Discussion}

The SCOP ${ }_{\min }$ value in each scenario is lower than those recorded in previous analyses (cf. $[28,31]$ ) where $\mathrm{SCOP}_{\min }$ was 3.5 ; thus, the progress in RES application improved the energetic viability. However, ASHPs are switched off when the temperature falls below the bivalent point, and then heat is generated by combusting a fossil fuel; hence, the capital expenditure rises.

Since ASHP is interchanged with the oil boiler below the bivalent temperature, indirect emissions occur in these locations. The possible non-emissive heat generator in this location is electricity; however, its application is highly improbable because of fixed charges for contracted power which must be paid independently of the lack of electricity consumption; this question is discussed thoroughly in [35].

The present analysis differs from earlier analyses [31]; these differences result from variances in the manufacturers of the applied equipment and slight changes in the Polish energy mix and unit emissions. The greater diversity is caused by disparate modeling of heat and power demand; in the previous analyses [31], these demands were determined using the monthly averaged outside temperatures, while in the present study, the temperatures were taken from the typical meteorological year at every hour in the heating season. The last variation results from the overestimated values of the indirect generation factors, except the values for $\mathrm{CO}_{2}$; after reasoning, we concluded that it would be more realistic to assume that indirect generation factors are in proportion to the direct unit emissions.

In comparison to the earlier analyses [31], an assessment of the ecological viability deteriorated, for no heat pump in the present Polish energy mix is ecologically viable; this means a condensing gas boiler emits significantly less pollution. Figure $3 \mathrm{~b}$ shows that it would only be slightly better in the case of carbon dioxide emissions in Zakopane if the Polish policy was implemented. To reduce the pollutants emissions so that GSHPs or WSHPs emit less pollution than natural gas-fired condensing boilers, the Polish energy mix must be changed fundamentally; these changes include replacing almost all of the coal-fired power stations with natural gas-fired gas turbines. These changes could be smaller if the efficiency of electrical energy transmission rose, which is related to the modernization of the electrical power grid.

It should be emphasized that the final decision regarding the selection of heat sources and the method of regulating the system operation should be preceded by a detailed analysis taking into account the local climatic, geological and hydrological conditions as well as the investment and operation costs of the facilities, for these factors affect the final investment profitability both economically and ecologically.

\section{Conclusions}

The method of heat generator regulation greatly affects both energetic viability and emission levels. The weather-compensated modulation of the buffer tank temperature using a heating curve is markedly better than using a fixed design flow temperature.

An increased share of the RES in electrical energy production in Poland improved the energetic viability of heat pumps, as SCOP $\min$ dropped from 3.5 in 2013 (cf. [28]) to 3.04 in the first scenario; a further drop to 2.23 was possible in the second scenario. Therefore, this ensures energetic viability even by ASHPs, which are the least efficient in Polish climatic conditions, in the first three warmer climatic zones, which was previously unviable (cf. [35]) and shortens the payback period for each heat pump type. 
For GSHPs and WSHPs, despite the ecological analysis, an investor should plan the expenditures on investigating geologic structure and physicochemical properties of groundwater basins, drilling wells or boreholes, purchasing and installing equipment and the operating system.

The planned changes to the Polish energy market will reduce the emissions of greenhouse gases and particulate matter into the atmosphere and thus contribute to the improvement of the climate situation. However, even the implementation of the Polish energetic policy will be by far insufficient in achieving the ecological viability of heat pumps, as the efficiency of electrical energy transfer and transformation is not the highest, and the condensing gas boiler will emit significantly less pollution. Therefore, natural gas-fired gas turbines should be applied in the transitional period before zero-emission energy production in Poland is achieved and the Polish electrical grid is modernized.

Author Contributions: A.G. and S.S. created a calculation algorithm, S.S. did the computations, S.S. and A.G. analyzed the data and wrote the paper. All authors have read and agreed to the published version of the manuscript.

Funding: The research was carried out at the Bialystok University of Technology at the Department of HVAC Engineering as the projects WI/WB-IIŚ/6/2021 and WZ/WB-IIŚ/4/2019; the paper was prepared at Students' Scientific Society "Heat Engineer" at Bialystok University of Technology. Both the research and paper were subsidized by the Ministry of Science and Higher Education of the Republic of Poland. The research was conducted using equipment which was purchased thanks to "Research on the efficacy of active and passive methods of improving the energy efficiency of the infrastructure with the use of renewable energy sources" - the project was co-financed by the European Regional Development Fund under the Regional Operational Programme of the Podlaskie Voivodship for the years 2007-2013.

Conflicts of Interest: The funders had no role in the design of the study; in the collection, analyses, or interpretation of data; in the writing of the manuscript, or in the decision to publish the results.

\section{References}

1. The Intergovernamental Panel on Climate Change Special Report Climate Change and Land. Available online: https://www. ipcc.ch/srccl/ (accessed on 25 May 2021).

2. European Commission. 2030 Climate \& Energy Framework. Available online: https://ec.europa.eu/clima/policies/strategies/ 2030_en\#tab-0-0 (accessed on 25 May 2021).

3. European Commission. A European Green Deal. Available online: https://ec.europa.eu/info/strategy/priorities-2019-2024/ european-green-deal (accessed on 22 June 2021).

4. European Commission. Communication From The Commission to the European Parliament, the Council, the European Economic and Social Committee and the Committee of the Regions. Energy Roadmap 2050; European Comission: Brussels, Belgium, 2011.

5. Forsyth, I. Carbon Footprint Country Specific Electricity Grid Greenhouse Gas Emission Factors. Available online: www. carbonfootprint.com (accessed on 21 July 2021).

6. The Council of Ministers of Republic of Poland. Resolution No.141 of the Council Of Ministers of October 2, 2020 on Updating the Multi-Annual Program under the Name "Polish Nuclear Energy Program"; The Council of Ministers of Republic of Poland: Poland, 2020; pp. 1-69. (In Polish)

7. Saner, D.; Juraske, R.; Kübert, M.; Blum, P.; Hellweg, S.; Bayer, P. Is it only $\mathrm{CO}_{2}$ that matters? A life cycle perspective on shallow geothermal systems. Renew. Sustain. Energy Rev. 2010, 14, 1798-1813. [CrossRef]

8. Bayer, P.; Saner, D.; Bolay, S.; Rybach, L.; Blum, P. Greenhouse gas emission savings of ground source heat pump systems in Europe: A review. Renew. Sustain. Energy Rev. 2012, 16, 1256-1267. [CrossRef]

9. Rubik, M. Refrigeration and Heat Pumps; Dom Wydawniczy MEDIUM Wydawnictwo: Warsaw, Poland, 2020.

10. PN-EN 12831-1:2017-08, Energy Performance of Buildings_-Method of Calculation of the Design Heat Load-Part 1: Space Heating Load, Module M3-3; The Polish Committee for Standardization: Warsaw, Poland, 2017.

11. Soltani, M.; Kashkooli, F.M.; Dehghani-Sanij, A.R.; Kazemi, A.R.; Bordbar, N.; Farshchi, M.J.; Elmi, M.; Gharali, K.; Dusseault, M.B. A comprehensive study of geothermal heating and cooling systems. Sustain. Cities Soc. 2019, 44, 793-818. [CrossRef]

12. Blum, P.; Campillo, G.; Kölbel, T. Techno-economic and spatial analysis of vertical ground source heat pump systems in Germany. Energy 2011, 36, 3002-3011. [CrossRef]

13. Blum, P.; Campillo, G.; Münch, W.; Kölbel, T. $\mathrm{CO}_{2}$ savings of ground source heat pump systems-A regional analysis. Renew. Energy 2010, 35, 122-127. [CrossRef] 
14. Todorov, O.; Alanne, K.; Virtanen, M.; Kosonen, R. A Novel Data Management Methodology and Case Study for Monitoring and Performance Analysis of Large-Scale Ground Source Heat Pump (GSHP) and Borehole Thermal Energy Storage (BTES) System. Energies 2021, 14, 1523. [CrossRef]

15. Poredoš, P.; Vidrih, B.; Poredoš, A. Performance and Exergy Analyses of a Solar Assisted Heat Pump with Seasonal Heat Storage and Grey Water Heat Recovery Unit. Entropy 2020, 23, 47. [CrossRef]

16. Stanek, W.; Simla, T.; Gazda, W. Exergetic and thermo-ecological assessment of heat pump supported by electricity from renewable sources. Renew. Energy 2019, 131, 404-412. [CrossRef]

17. Smith, M.; Bevacqua, A.; Tembe, S.; Lal, P. Life cycle analysis (LCA) of residential ground source heat pump systems: A comparative analysis of energy efficiency in New Jersey. Sustain. Energy Technol. Assess. 2021, 47, 101364. [CrossRef]

18. Lin, H.; Clavreul, J.; Jeandaux, C.; Crawley, J.; Butnar, I. Environmental life cycle assessment of heating systems in the UK: Comparative assessment of hybrid heat pumps vs. condensing gas boilers. Energy Build. 2021, 240, 110865. [CrossRef]

19. Decano-Valentin, C.; Lee, I.-B.; Yeo, U.-H.; Lee, S.-Y.; Kim, J.-G.; Park, S.-J.; Choi, Y.-B.; Cho, J.-H.; Jeong, H.-H. Integrated Building Energy Simulation-Life Cycle Assessment (BES-LCA) Approach for Environmental Assessment of Agricultural Building: A Review and Application to Greenhouse Heating Systems. Agronomy 2021, 11, 1230. [CrossRef]

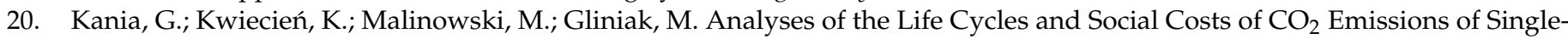
Family Residential Buildings: A Case Study in Poland. Sustainability 2021, 13, 6164. [CrossRef]

21. Bellos, E.; Tzivanidis, C. Parametric Investigation of a Ground Source $\mathrm{CO}_{2}$ Heat Pump for Space Heating. Energies 2021, 14, 3563. [CrossRef]

22. Ghanbarpour, M.; Mota-Babiloni, A.; Badran, B.E.; Khodabandeh, R. Theoretical Global Warming Impact Evaluation of Medium and High Temperature Heat Pumps Using Low GWP Refrigerants. Appl. Sci. 2021, 11, 7123. [CrossRef]

23. Remiorz, L.; Hanuszkiewicz-Drapała, M. Cumulated energy consumption in a heat pump system using a U-tube ground heat exchanger in a moderate climate. Energy Build. 2015, 96, 118-127. [CrossRef]

24. Pater, S. Field measurements and energy performance analysis of renewable energy source devices in a heating and cooling system in a residential building in southern Poland. Energy Build. 2019, 199, 115-125. [CrossRef]

25. Fidorów, N.; Szulgowska-Zgrzywa, M. The influence of the ground coupled heat pump's labor on the ground temperature in the boreholes-Study based on experimental data. Appl. Therm. Eng. 2015, 82, 237-245. [CrossRef]

26. Szulgowska-Zgrzywa, M.; Fidorów-Kaprawy, N. Performance analysis of a brine-to-water heat pump and of its boreholes' temperature change during three years of operation. Appl. Therm. Eng. 2017, 127, 233-244. [CrossRef]

27. Rynkowski, P. The energy source for heat pumps with vertical heat exchangers. E3S Web Conf. 2018, 44, 00157. [CrossRef]

28. Gajewski, A.; Siergiejuk, J.; Szulborski, K. Carbon dioxide emission while heating in selected European countries. Energy Build. 2013, 65, 197-204. [CrossRef]

29. Jadwiszczak, P.; Jurasz, J.; Kaźmierczak, B.; Niemierka, E.; Zheng, W. Factors Shaping A/W Heat Pumps $\mathrm{CO}_{2}$ EmissionsEvidence from Poland. Energies 2021, 14, 1576. [CrossRef]

30. Polska Organizacja Rozwoju Technologii Pomp Ciepła Heat pump market in Poland in 2019 and in the Perspective until 2030 (In Polish). Available online: https:/ / portpc.pl/rynek-pomp-ciepla-w-polsce-w-2019-roku-i-w-perspektywie-do-roku-2030/ (accessed on 21 February 2021).

31. Sewastianik, S.; Gajewski, A. Energetic and ecologic heat pumps evaluation in Poland. Energies 2020, 13, 4980. [CrossRef]

32. Ministry of Climate and Environment of Republic of Poland. Energy Policy of Poland until 2040, Extract. Available online: https: / / www.gov.pl/attachment/7ba82820-4a14-4bb8-a84a-a0bb51c6d432 (accessed on 20 March 2021).

33. EnergyPlus All Regions-Europe WMO Region 6-Poland. Available online: https://energyplus.net/weather-region/europe_ wmo_region_6/POL/ (accessed on 15 January 2020).

34. The Polish Committee for Standardization. PN-B-02025:2001 Calculation of the Seasonal Heat Demand for Heating Residential Buildings and Collective Residence; The Polish Committee for Standardization: Warsaw, Poland, 2001. (In Polish)

35. Gajewski, A.; Gładyszewska-Fiedoruk, K.; Krawczyk, D.A. Carbon dioxide emissions during air, ground, or groundwater heat pump performance in Białystok. Sustainability 2019, 11, 5087. [CrossRef]

36. Polska Grupa Energetyczna, S.A. Information for Customers on the Structure of Fuels Used to Generate Electricity Sold by PGE Polish Energy Group S.A In 2020, in Accordance with § 37 of the Regulation of the Minister Of Economy of 4 May 2007 on the Detailed Conditions for the Operation. Available online: https://www.gkpge.pl/bip/Struktura-paliw (accessed on 30 March 2021).

37. Kowalski, J. Hydrogeology with Basic Geology; III revise; Wydawnictwo Uniwersytetu Przyrodniczego we Wrocławiu: Wrocław, Poland, 2007. (In Polish)

38. Majorowicz, J. The course of the geothermal degree in Poland in the depth range of 200-2500 m. Kwart. Geol. 1971, 15, 891-900. (In Polish)

39. Nowicki, Z. The Groundwater of the Voivodeship Capitals in Poland, 1st ed.; Państwowy Instytut Geologiczny: Warszawa, Poland, 2007. (In Polish)

40. Małopolska. Geological Cross-Section throught the Podhale Aqiufer-Recharge and Flow Patterns of Groundwaters. Available online: https://www.malopolska.pl/_userfiles/uploads/SR/wody_geotermalne_malopolski_32.pdf (accessed on 21 March 2021).

41. Oleskowicz-Popiel, C.; Wojtkowiak, J.; Prętka, I. Effect Of Surface Cover On Ground Temperature Season's Fluctuations. Found. Civ. Environ. Eng. 2002, 1, 151-164. 
42. Heat Pump Controller. Instructions for the Installer. Available online: https://storage.glen-dimplex.pl/resources/document/54 2ace764c213.pdf (accessed on 28 March 2021). (In Polish).

43. PN-EN 14825:2019-03, Air Conditioners, Chillers for Liquid Cooling and Heat Pumps with Electrically Driven Compressors, for Heating and Cooling Rooms-Testing and Evaluation Part Load Conditions and Calculation of Seasonal Capacity; The Polish Committee for Standardization: Warsaw, Poland, 2019.

44. Ciura, S. Distribution charges related to reactive power consumption by the customers. Energ. Elektr. 2011, 2, 1-10. (In Polish)

45. Taylor, P.; D'Ortigue, O.L.; Trudeau, N.; Francoeur, M. Energy Efficiency Indicators for Public Electricity Production from Fossil Fuels; OECD/IEA: Paris, France, 2008.

46. Breeze, P. Modern Gas Turbine Design for Power Generation. In Power Generation Technologies, 3rd ed.; Elsevier: Amsterdam, The Netherlands, 2019; ISBN 978-0-0810-2631-1. 